Çetin, U. (2021). 20. yüzyıl öncesi Amerikan portreciliği hakkında bir değerlendirme. Uludağ Üniversitesi Fen-Edebiyat Fakültesi Sosyal Bilimler Dergisi, 22(41), 785-838.

DOI: $10.21550 /$ sosbilder.835477

Araştırma Makalesi / Research Article

\title{
20. YÜZYIL ÖNCESİ AMERIKKAN PORTRECİLİĞİ HAKKINDA BİR DEĞERLENDİRME
}

Ufuk ÇETIN*

Gönderim Tarihi / Sending Date: 3 Aralık / December 2020

Kabul Tarihi / Acceptance Date: 1 Şubat / February 2021

\section{ÖZET}

Bu makalenin konusunu 20. yüzyll öncesi Amerikan portreleri oluşturmaktadır. Öne çıkan portre ressamları ve bazı çalışmaları ile dönemler tanıtılmaya çalışılmıştır. Portre sanatı tanitılırken tarihsel bağlamda Amerika kıtasında yaşanılan siyasi, sosyal, ekonomik, kültürel oluşum ve dönüşümler de incelenmiştir. Kolonileşme Dönemi ile Erken Cumhuriyet Dönemleri arasında, Amerikan portresi tarz ve konu bakımından değişmişti. 19. yüzyılın ilk dönemlerinde, kendine özgü millî bir Amerikan tarzı oluşmuştur. Portrelerde Amerika'ya Kolonileşme Dönemi'nde çeşitli ülkelerden ve çeşitli kültürlerden, çoğu yetersiz eğitimi olan pek çok ressam da gelmiş ve Amerikan sanatının gelişimine katkı sağlamışlardır. Kıtada yaşayan siyahi ve diğer yerli grupları da Amerika kıtasının potasında kendi kültürleriyle var olmuş ve özgün bir Amerikan sanatı oluşumuna destek vermişlerdir. Amerikan portre sanatı geniş bir üretim evresini kapsaması nedeniyle bütün Amerikalı ressamlara bu makalede yer vermek mümkün olmamıştır.

Anahtar Kelimeler: Kolonileşme Dönemi, resim, Amerikalı ressamlar, Amerikan resim sanatt, portre

\section{An Assessment of American Portraiture before 20th Century}

ABSTRACT

The subject of this article is American portraits before the 20th century. Periods were introduced with prominent portrait painters and some of their Works. While introducing

Dr., Tekirdağ Namık Kemal Üniversitesi Çorlu Mühendislik Fakültesi, Tekirdağ / TÜRKIYE, ucetin@nku.edu.tr

Uludağ Üniversitesi Fen-Edebiyat Fakültesi Sosyal Bilimler Dergisi Uludağ University Faculty of Arts and Sciences Journal of Social Sciences

Cilt: 22 Sayı: 41 / Volume: 22 Issue: 41 
the art of portrait, the political, social, economic and cultural formations and transformations experienced in the American continent were also examined. Between the colonial period and the Early Republic, the American portrait changed in style and subject matter. In the early nineteenth century, a distinctive national American style emerged. During the colonization period, many painters from various countries and various cultures came and contributed to the development of American art, most of them with inadequate education. Black and other indigenous groups living in the continent existed in the pot of the Continent with their own cultures and supported the formation of a genuine American art. Since American portrait art covers a wide production phase, it was not been possible to include all American painters in this article.

Key words: Colonial Period, painting, American painters, American painting art, portrait

\section{Giriş}

Her resim türü gibi, portre sanatı da hâkim resim stilini yansitıyordu. Erken Misır'da, portreler ve kabartma heykeller konuyu sadece profilde gösteriyordu. Barok Dönemi'nde yapılmış bir portre, Neo-klasik resimlerden daha coşkulu olurdu, ancak ikisi de Realistlerinki kadar gerçekçi değildi (Lee, 1929: 159). Benzer şekilde, Romantik portre, Empresyonist portrelerden daha hareketliyken, yirminci yüzyılın başlarından kalma Ekspresyonist portre, tipik olarak tüm dönemlerin en gösterişli ve renklisi olmaktadır. Bununla birlikte, çok basit bir ifadeyle, portrede iki temel stil veya yaklaşım saptanmaktadır: Birincisi öznenin daha idealize edilmiş veya "yaşamdan daha büyük" bir biçimde tasvir edildiği "büyük stil"; ikincisi ise konunun daha gerçekçi bir şekilde temsil edildiği gerçekçi, “yalın üslup”tur. Güzel sanatlarda portre, yüzün ana tema olduğu bir heykel, resim, fotoğraf biçimi veya bir kişinin başka bir temsili olabilmektedir. Geleneksel şövale tipi portreler genellikle baş ve omuzları, yarı uzunlukta veya tam gövdeyi göstermektedir. Bir kişinin geleneksel olarak portresi, bir grup portresi veya bir otoportre de dâhil olmak üzere çeşitli portre türleri bulunmaktadır. Çoğu durumda, resim, konunun karakterini ve özelliklerini tasvir etmek için özel olarak 
oluşturulmuştur. Batı Sanatının büyük portre ustaları arasında, Rönesans'1n Floransalı Leonardo da Vinci (doğ. 1452 - öl. 1519), Michelangelo (1475-1564) ve Bronzino (1503-1572), Toskana Raphael (1483-1520) gibi eski Avrupalı ustalar vardır.

Venedikli Titian (1487-1576), Alpler' in kuzeyinde, Bruges'den Flaman resminin kurucusu Jan van Eyck (1390-1441) ve Alman portreciler Lucas Cranach the Elder (1472-1553) ve Hans Holbein the Younger (1497-1543) da bulunmaktadir. Daha sonraki ustalar arasında ölümsüz Hollandalı Rembrandt (1606-1669) ve Barok ressam Anthony Van Dyck (1599-1641), İspanyol saray ressamı Velazquez (1599-1660) ve İngiliz ressam Thomas Gainsborough (1727-1788) yer almaktadir. En geniş portre koleksiyonu, yaklaşık 200.000 örneğe sahip olan Londra Ulusal Portre Galerisi'nde günümüzde bulunmaktadır. Pek çok insan, özellikle tarih boyunca sanatçıların kişilikleri hakkında fikir edinmenin bir yolu olarak otoportreden etkilenir. Portrelerin bize konuları hakkında hikâyeler anlatmasına benzer şekilde, otoportreler de bize sanatçıların iç yaşamları hakkında bir şeyler söyleyebilir. Fotoğrafın icadından önce, bir portre, birinin görünüşünü kaydetmenin tek yolu olmuştur. Ancak portreler her zaman bir kayıt özelliğinden daha fazlasına sahiptir.

Portre kişinin gücünü, önemini, erdemini, güzelliğini, zenginliğini, zevkini veya diğer özelliklerini göstermek için kullanılmıştır. Portreler eskiden beri ülkelerde dışa dönük bir statü kaynağı olarak kabul edilegelmişlerdir. Duvarlarda asılı duran bir portre kişilerin özellikle özel bir şey hazırlatmak için yetenekli bir sanatçı tutabileceğinizi de düşündürtmektedir. Portre, bir kişinin yüzünün ve ifadesinin baskın olduğu bir resim, fotoğraf, heykel veya diğer sanatsal temsilidir. Amaç, kişinin benzerliğini, kişiliğini ve hatta ruh hâlini sergilemektir (Cook \& Gardner, 1964: 16). Kişilerin portreleri, sanatçıların figürü ele almasına yardımcı olmaktadır. Bir sanatçı bir portreyi ne kadar çok işleyebilirse, sadece o kişi kendisi olsa bile, bir sanatçı insanları tasvir etmede o kadar başarılı olabilmektedir. İnsan 
formu, üstesinden gelinmesi oldukça karmaşık bir konudur, bu nedenle ne kadar çok pratik olursa o kadar iyi sonuçlar alınabilmektedir.

Tematik olarak Amerikalı ressamlar portre, manzara çalışmaları, Amerika'nın batısına ve hatıra sanatına yoğunlaşmaktadır. Sonrasında ressamların tarıma dayalı eski bir koloniden sanayileşmiş bir koloniye doğru yaşadığı hızlı dönüşümden kaynaklanan büyük, sosyal ve ekonomik değişikliklere karşı nasıl bir tavır sergilediklerini yansıtır.

Portreler, kişisel olmayan ve kamusal (statü, meslek veya grup kimliği) çok bireysel özelliklere (görünüm, ifade veya cinsiyet) kadar değişen şaşırtıcı sayıda niteliği bünyesinde barındırmaktadır. Sanatçılar izleyicileri, kameraya "iyi tarafınızı" çevirmek, ciddi görünmeye çalışmak veya dikkati belirli bir sosyal konuya odaklamak gibi belirli bir izlenimi aktarmak için portreleri kullanmaktadır.

Akıllı telefonlar, kendimizin, arkadaşlarımızın ve ailemizin görüntülerini ulaşabileceğimiz bir yerde tutmamızı sağlamaktadır, böylece onlara her an bakabilir veya başkalarına gösterebiliriz. 18. yüzyılın sonları ve 19. yüzyılın başlarında sanatçılar, sahibinin veya kullanıcının benzer şekilde yakın tutabileceği taşınabilir minyatür portreler de yaptılar (Salvo, 1995: 96). Bu küçük resimler güzel sanatların bir parçası olarak kabul edilmiş, tıpkı büyük portreler gibi yaptırılmışıı; ancak yalnızca bunların maliyetini karşılayabilecek kişiler tarafından kullanılabilmiştir.

Taşınabilir portrenin bir başka biçimi de, Fransızcada "ziyaret kartı" anlamina gelen "carte-de-visite" olmuştur. 1850'lerde Fransa'da icat edilmiş ve hızla Amerika Birleşik Devletleri'ne ulaşmıştır. Portrenizin yanı sıra adınız ve adresinizi de taşıyan cartes-de-visite, fotoğrafçılığın ilk ucuz, ana akım biçimiydi (Romero, 1985: 259). Bazen kişisel hatıra olarak da taşınan popüler ama daha pahalı "dagerreyotiplerinin" yerini almışlardır. 1860'ların başlarında ziyaret kartlarında yaşanan bir çılgınlık Amerikalıları adeta tüketmiştir. İnsanlar 
bunları takas etmiş, albümler yapmışı ve hatta ünlülerin ve "Sojourner Truth" gibi para toplamak için "cartes-de-visite" satan önemli kişilerin resimlerini toplamıştır.

Yüzyıllar boyunca portreler, Amerikan halkının önemli bir kayıt belgesi olmuştur. Amerika'nın ilk başkanını düşündüğünüzde, akla gelen imaj muhtemelen portreci Gilbert Stuart'ın George Washington isimli çalışmasıdır. Bu resim 1795 yılında yapılmıştır (Barratt \& Zabar, 2010: 26). Gilbert geniş omuzlu, kırmızı yüzlü ve bize bakan ciddi bir başkanı göstermektedir. Amerika'nın ilk kolonilerini, koloniyel dönemini, liderlerini, politikacılarını, tüccarlarını ve filozoflarını portreler aracılığıyla tanınmaktadır. Bu kişiler, bilinçli bir şekilde, sanatçılarla birlikte, gelecek nesiller tarafından nasıl hatırlanmak istediklerine dair halka açık anıtlar inşa etmişlerdi. Ressamlar ise kişilerin dikkatli olma, liderlik ve güç gibi kişisel niteliklerini resimlerde yansıtmışlardır. Portre resimlerinde askerî, mesleki, annelik, zenginlik, siyasi kimlik ve sosyal roller gibi kavramlar da bulunuyordu.

Kolonileşme Dönemi 1607'den 1776'ya kadar erken Amerikan tarihini ve Amerikan Devrim Savaşı'na ve anayasanın kurulmasına yol açan olayları kapsayan döneme verilen isimdir. Kuzey Amerika kıtasının ve halklarının işgali 1565 'te St. Augustine, Florida'da İspanyollarla başlamış, ardından 1587 'de Plymouth Company'nin bugünkü Virginia'da Roanoke adını verdikleri bir yerleşim kurmasıyla İngilizlerle devam etmiştir. Bu ilk yerleşim gizemli bir şekilde başarısız olmuş ve 1606'da Londra Şirketi, Jamestown, Virginia'da bir varlık oluşturmuştur. Daha sonra, Fransızlar 1608'de Quebec'i kurmuş, ardından Hollandalılar bugünkü New York'ta 1609'da bir koloni oluşturmuşlardır. Yerli Amerikalılar bu dönemde Avrupa'nın toprak ve güç toplama çabalarına karşı direnirken, bir yandan da Avrupalıların getirdiği yeni hastalıklar ve köle ticareti ile mücadele etmiş bir yandan da anayurtlarını savunmak zorunda kalmışlardır. 
Kolonileşme Dönemi yerleşimcileri birçok nedenden dolay1 Amerika'ya gelmişti. Gelen kişilerin bazıları dini özgürlük bazıları ise para kazanmak için gelmiş̧i. Gelen bu kişiler, New York, New Jersey, Pennsylvania, Virginia, North Carolina, South Carolina, Massachusetts, New Hampshire, Maryland, Georgia, Connecticut, Rhode Island ve Delaware olarak bilinen on üç eyalete yerleşmiştiler. Günümüzde Florida olarak bilinen yerde St. Augustine gibi başka dağınık koloniler de ortaya çıkmıştı.

Kolonileşme Dönemi'nin ilk günlerinde, yerleşimciler vahşi doğada nasıl yaşayacaklarını bilmemiş ve birçok zorlukla karşılaşmıştılar. Örneğin Massachusetts'te, Plymouth yerleşimcileri ilk kışlarının çoğunu (1620-1621) Mayflower'da geçirmiştiler. Ertesi kış, karada, yelken bezi çadırlarında yaşamış ve çoğu hastalık ve açlık içinde yaşamak zorunda kalmıştı. İngiltere'den bir gemi yeni malzeme getirmeden önce gelen bu kişilerin yaklaşık dörtte biri ölmüştü.

Zamanla, Kolonileşmeciler, deneme yanılma yöntemiyle ve daha dost canlısı Amerikan Yerlilerinin bazı kabilelerinin yardımıyla vahşi doğada nasıl yaşayacaklarını öğrenmiştiler. 1700'lerde küçük şehirler ve kasabalar daha iyi koşullarda kurulmuştu. Kolonistler yavaş yavaş kendi geleneklerini ve yaşam tarzlarını geliştirmiştiler. Sonunda yeni kıtanın ve toprağın artık gerçek evleri olduğunu hissetmeye başlamışlardı.

Kolonileşme Dönemi Amerika'da yaşam; aile merkezli olmuş, çoğu insan evde çalışmış, oynamış, öğrenmiş ve dini inançlarını yerine getirmişti. Öte yandan bu dönemlerde tüm işleri halletmek için büyük bir aile gerekli olmuş, babalar, evin reisi olarak kabul edilerek aileleri ile ilgili tüm kararları alarak ev dışındaki çiftçilik ve diğer işlerden para kazanmışlardı. Kadınlar evde çalışmış, çocukları yetiştirmiş, yemekleri hazırlamış, kıyafet dikmiş, kış için yiyecek saklamış, çamaşırları yıkamış, su getirmiş ve ateş yakmışlardı. 
Kolonileşme Dönemi'nde Amerika'da ve cumhuriyetin ilk yıllarında portrelere erişim sınırlıydı. Portreler, büyük ölçüde Avrupalı Kolonileşmecilere veya göçmen Amerikalılar için bu pahalı lüksü satın alıp evlerinin içine portre resmi asabilecek çok az kişi bulunuyordu (Barratt, 2003: 41). Portreler ekonomi büyüdükçe, genellikle kendi kendini yetiştiren portrecilerden oluşan bir girişimci sınıf, aile soylarını gelecek nesiller için taşımak isteyen, büyüyen bir orta sınıfa hizmet etmeye başlamıştı. 19. yüzyılın başlarında portre alanında çalışan az sayıdaki Afrikalı Amerikalı sanatçıdan Joshua Johnson, Grace Allison McCurdy (Bayan Hugh McCurdy) ve kızları, Mary Jane ve Letitia Grace gibi 1806 dolaylarında bu türde birçok aile portresi çalışması hazırlamıştı (Resim 13). Bu çalışmada ev içi ortamı figürleri yüksek arkalıklı bir kanepede oturması gibi unsurlarla, anne ve kızları tarafından iletilen samimiyet ve hassasiyet, görülmektedir. Fakat bu çalışma bir başka portre sanatçısı olan Gilbert Stuart'ın kamusal portresinden tarz olarak ayrılmaktadır.

19. yüzyıldan itibaren, yeni teknoloji, ülkenin genişlemesi, sosyal ve politik değişim, sanatçıları fotoğraf gibi modern medyayı ve sanatçı ile özne arasındaki ilişkideki değişiklikleri esas alan yeni yaklaşımları benimsemeye teşvik etti (Burke, 1986: 72). Bu değişen dinamik, George Catlin'in Amerikan Kizılderilileri portrelerinden ikisi olan The Female Eagle - Shawano, 1830 ve Boy Chief - Ojibbeway, (Resim 14) 1843'te görülmektedir. Catlin, bu bireyleri yerli kültürün ortadan kaybolması olarak gördüğü şeye olan kişisel ilgisinden dolayı resimlemiştir. $\mathrm{Bu}$ resimleri yaparken ticari amaç taşımadığını sadece bunu belgeleme dürtüsünden yaptığını da belirtmiştir. $\mathrm{Bu}$ arada, fotoğrafçılığın ortaya çıkması, ilk fotoğraf albümlerinde takas edilen ve toplanan ucuz baskıların görünmesine neden olmuştu. Bunlar, kölelik karşıtı ve aktivist "Sojourner Truth"un bir portresi, 1864 gibi farklı sosyal siniflardan insanların görüntüleri ve belirli idealleri somutlaştıran bireylerin tasvirlerini içermektedir. Portresine "Maddeyi Desteklemek İçin Gölgeyi 
Satıyorum" diye bir başlık eklemiştir. Bu şekilde insanların inançlarını arttırmak amacıyla imajını güçlendirdiğini belirtmişti.

20. yüzyılın sanatçıları portrenin amaçlarını genişletmeye devam etmişti. James Van Der Zee, Harlem'de bir fotoğraf stüdyosu açtı ve Harlem Rönesansı sırasında Afrikalı Amerikalıların yaşamlarını kapsamlı bir şekilde belgeledi ve dönemin önemli bir ayrıntısını verdi (Clark, 1992: 38). 1926 Sisters, Georgia O'Keeffe, 1924 gibi diğer görüntüler, ortağı Alfred Stieglitz tarafından çekilen ressam, Amerikan bireycilik anlayışını yansıtmaya başlamıştı. Küçük Kız Beyaz (Queenie Burnett), 1907'de ressam George Bellows, çocuk işçiliği yasalarının onları korumasından önceki bir dönemde marjinalleştirilmiş sokak çocuklarının yaşamlarına dikkat çekmişti.

Bellows'un çalışmasını John Singer Sargent'1n 1882'deki Miss Beatrice Townsend'in (Resim 18) bir nesil önceki çalışmalarıyla karşılaştırıldığında; iki kız Amerikan toplumunda büyük zıtlıklar taşıdığ 1 görülmektedir (Clark, 1972: 49). Diğer sanatçılar, 1937'de Siwa yakınlarındaki Space of Space'deki Lee Miller gibi portrenin özelliklerini ve belki de temsilin sınırlarını keşfetmeyi seçmişti.

Portre türünün sınırları daha da genişledikçe deneysel çalışmalarda devam etmişti. Çağdaş portreler, yalnızca bir kişinin kimliğinin ve görünüşünün görünen işaretlerini değil, aynı zamanda kendimizi tanımladığımız diğer yolları da ortaya çıkarmaktadır. Bunlar arasında uyum sağlamak veya anlaşmazlığa düşmek, yer, ev, toplulukla bağlantılar, iş, vatandaşlık, kişisel yaşamla özdeşleşmek gibi kavramlar bulunmaktadır. Fotoğrafçı Milton Rogovin, Working People serisinde (1972-1987), kırsal Amerika'daki esnaf ve fabrikalarda çalışan işçi sınıfından insanları belgelemişti. Barkley Leonnard Hendricks ve Andy Warhol moda ve kişisel sunum (George Jules Taylor, 1972 ve 1980’lerin iki Warhol otoportresi) ve kimliğin ve görünüşün değişebileceği sayısız yolu araştıran diğer önemli çalışmalar arasında kabul edilmektedir. 
Portre sanatçıları ve izleyicileri temsil ve kimliğe yönelik yeni biçimleri ve yaklaşımları öğrendikçe portre aracılığıyla kendimizi nasıl resimlerle ifade ettiğimiz konusu yüzyıllardır gelişmeye devam etmektedir.

\section{Amerikan Portre Sanatı}

Araştırmada 20. yüzyıl öncesi Amerika'daki portre çalışmaları oldukça fazla olduğundan konu araştırılırken bazı ressamlar ve öne çıkan çalışmaları seçilmiştir. Ressamlar ve portre çalışmaları tanıtılırken ressamların doğum tarihlerine göre kronolojik bir yöntem kullanılmıştır.

İlk Amerikan halk portreleri, Kolonileşme ve Devrimci portreciliğin kardeşi olarak görülmektedir. Kolonileşme ve Devrimci sanat, İngiliz kültürel normlarına hep bağlı kalmıştır. Çünkü Koloniciler, İngiltere'deki çağdaşlarının satın aldıkları gibi portreler satın almak istemişlerdi (Gardner \& Feld, 1965: 70). Portre, kişinin yüksek sosyal konumunun bir göstergesiydi. Bu alışkanlık Amerika'nın seçkin bir sanatı olarak kabul edilen portre sanatını Yeni Cumhuriyet'in başlangıcına kadar sürekli kendisini devam ettirmiştir.

Kolonileşme Dönemi'ne özgü ancak daha doğrudan Devrimci ve Erken Cumhuriyet portresine özgü olan şey, klasik İngiliz tarzlarıyla sürdürülmesine rağmen, bazı ressamlar farklı düşünerek resimlerinde İngiliz geleneğinden ayrılmış ve sorunlar çıkmıştı. Bu gerilimler farklı tarzları benimseyen Amerikan portre ressamlarının çalışmalarında belirgin durumda olmuştu. Ayrıca bu problemler, Amerikalıları İngiliz kültürüne bağlayan bağlara Yeni Cumhuriyet'in ilk neslinde hem akademik hem de ilk resimlere meydan okunduğu için Amerikan sanatını şekillendirecek değişikliklere işaret etmişti. Bu dönem, bir orta sınıfın ortaya çıkmasıyla yeni bir sanatsal türe, patronları, müşterileri ve sanatçıları aynı şekilde etkileyen Amerikan kimliğinin ortaya çıkmasına yardım ederek yeni bir halk portresi kavramını başlatmıştı. 
Amerikan portrelerde, bazen insanlar kendileri için kişisel anlamı olan nesneler ve aksesuarlar ile resmedilmiştir. Bu resimdeki (Resim 16) portrede ressam bir bitki veya bir bitki parçasını destek olarak seçmiştir. Sanat tarihinde, farklı bitkiler, saflık veya sadakat gibi çeşitli soyut nitelikleri sembolize etmektedir. $\mathrm{Bu}$ arada bitkiler, her müşterinin entelektüel uğraşları ve ilgi alanlarıyla doğrudan ilişkilidir. Ayrıca resimler, müşterilere yakın sanatçılar tarafindan oluşturulan samimi portreler olmuştur.

Benjamin West (1738-1820), John Singleton Copley (17381815), Charles Wilson Peale (1741-1827) ve Samuel FB Morse'un (1791-1872) profesyonel yaşamları üzerine yapılan bir çalışmada, Kolonileşme, Devrimci ve Erken Cumhuriyet portresi örnekleri arasındaki farklılıklar görülmektedir (Gardner, 1944: 63). Hemen hemen her sanatçı, kişisel duygularına rağmen, klasik İngiliz tarzlarının İngiliz kültürünün mirasını yansıttığı, Amerikan'dan çok bir İngiliz sanat geleneğini içeren dönemde çalışmıştır. 19. yüzyılda Amerikalı portre sanatçıları İngiltere ile kültürel bağlarını koparmaya başlamıştı. Bu sanatçılar, milliyetçilik ve Amerikan kimliği fikirlerinin hararetle tartışıldığı bir dönemde çalışmıştı (Garrett, 1970: 13). Açıkça bir Amerikan ruhu, yaratıcı stillerle portrelerde kendini gösterdi ve tüm sınıflara portre satın alma çağrısı yaptı. Sanatçılar, daha az ayrıntıyla daha hizlı resim yaparak stillerini maddi olarak daha uygun hâle getirerek daha fazla sınıf düzeyine ulaşmaya çalışmıştı. Böylece, 19. yüzyılda Amerikan beyaz orta sınıfında bir şey değişti ve ilk bağımsız Amerikan sanatsal türü olarak portre ortaya çıkmıştı. Aristokrat himayesi olmadan ve sanata karşı çok az ilgi gösteren insanlarla çalışmalarına devam eden Amerikalı sanatçılar, maddi destek bulmakta zorlanmıştı. Portrelere yönelik artan talep, portreciliği, ressamların geçimlerini sağlamanın en uygun yolu hâline getirmişti. Sonunda pek çok sanatçı bu resim türüne yönelmişti. Sanatsal bir uğraşı olarak iş ve ticari yönler özellikle portre resminde belirgin olmuştu. Sanatçılar, geleneksel olarak tarihsel 
konuların resmini sanatsal hiyerarşinin en üst kısmında, portre sanatını ise en altta görmüşlerdi. Sağladığı maddi kazançlara rağmen sanatçılar, portre resmini sınırlayıcı ve küçümseyici görerek daha prestijli sanat türlerini yapmak istemişti çünkü sanatçının öznenin kişisel gösterişine uyum sağlamak için sanatını feda etmesi gerekmişti.

John Smibert ise (1796-1872), Kolonileşme Dönemi'nde Amerika'da bir varoluş yaratmaya çalışan ilk portre ressamı olmuştu.

Smibert İskoç bir ressam olup, Londra eğitim almış, ardından İtalya'ya seyahatlerde bulunmuştur. Smibert'in Londra'daki portre çalışmaları oldukça dikkat çekicidir. Sonrasında Amerika'ya gelmiş ve üslubu değişip gelişmiştir. Smibert' in başyapıtı "The Bermuda Group" olarak kabul edilmektedir. En son yaptı̆̆ı en önemli çalışmaları, Boston'daki portre resim çalışmalarıdır (Smibert, 1995).

Saunders'a göre Smibert'in portreleri Kolonileşme toplumda portreciliğin doğası hakkında temel ipuçları sağlıyor (Perry, 1976: 46). Saunders, Smibert ve dönemin diğer sanatçılarının sosyal kodlarını, etnik önyargılarını ve dini entrikalarını tartışmıştı. Ayrıca Smibert'in İskoç Presbiteryen mirasının getirdiği manevi refah arayışı ile sanatsal başarı, sosyal kabul ve maddi güvence mücadelesi arasındaki çatışmaları nasıl uzlaştırdığını anlatmıştır. Katalog çalışmasında, sanatçının yüz otuzdan fazla eseri listelenmiştir.

Smibert'in portresi (Resim 9) James ve Hannah Penhallow Pemberton'ın kızı Hannah Pemberton (1734) Boston'da doğmuş ardından 1739'da, yine Smibert tarafından resmi yapılmış Bostonlu bir tüccar olan Benjamin Colman’ın ikinci eşi olmuştur.

John Singleton Copley (1738-1815) Boston'da doğmuş ve orada yaşamış başka bir Amerikalı ressam olup, 1727'de göç etmiş ve 1748'de Copley'in dul annesiyle evlenen üvey babası Peter Pelham'ın yanında görsel sanatlar eğitimi almıştı. Copley'in 1750'lerin ortalarına ait ilk resimleri, İngiliz mezzotint portrelerinin yanı sıra yerel ve gezici 
sanatçıların çalışmalarını ortaya çıkarmaktadır. Birçok teknik denemişti bunlar arasında tuval üzerine yağlı boya, bakır veya fildişi üzerine minyatürler, pastel ve baskı resim bulunmaktadır. 1750'lerin sonunda portre ressamı olmaya karar vermişti (Resim 2).

Copley, 1771'de New York'a altı aylık bir resim gezisi dışında 1774'e kadar hep Boston'da çalışmıştı. 1760'ların ortalarında çalışmalarını İngiltere' deki çağdaşlarınınkilerle karşılaştırmak istemiş ve 1765 'te kardeşi Henry Pelham, abisinin "Boy with a Squirrel” isimli çalışmasını, Society of Artists of Great Britain'ın yıllık sergisine göndermişti. Benjamin West ve Joshua Reynolds tarafından da cesaretlendirilen Copley, Avrupa'da eğitim almak için Boston'dan ayrılmıştı. 1774'te Londra'ya ardından hemen İtalya'ya gitmiş burada bir yıldan fazla kalarak resim yapmıştı. 1775'te Londra'ya döndü, eşi ve Boston'dan gelen üç çocuğuyla oraya yerleşti (Prown, 1966).

1776 yılı, Copley'in kariyerinin ikinci yarısının başlangıcı oldu. Kraliyet Akademisi'ndeki ilk çalışması olarak, 1777'de yaptığı Copley Ailesi'ni ve bir yıl sonra "Watson and Shark" isimli çalışmasını sergiledi. $\mathrm{Bu}$ resimlerin başarısı ona eleştirmenlerin övgüsünü kazandırdı ve akademiye tam üyelik sağladı. Onun en büyük tutkusu, Benjamin West'inki gibi çağdaş ressamların ve önemli olayların büyük tarihi resimlerini yapmaktı. En sonunda eserlerini bağımsız olarak sergiledi (Miles, 1995: 20-21).

Sanatçı Benjamin West (1738-1820) Amerikan Devrimi’nden çok önce, 1760'ta koloni etkisinden ayrılmış, henüz olgunlaşırken bile, Londra'ya yerleşmeden üç yıl boyunca İtalya'da eğitim görmüştür. Copley Londra'ya geldiğinde, West, İngiltere'nin en önde gelen tarih ressamlarından biri olarak ün yapmıştır. 1772'de tarihi ressam olarak Kral III. George'a hizmet etmesi için görevlendirilmiştir. Çoğu zaman Amerikalı bir ressam olarak tanımlansa da West, esasen Amerikalı 
ressamlar üzerindeki etkisi derin olan bir İngiliz ressamdır (Philadelphia Museum of Art, 1928) (Resim 6).

Joshua Johnson, (1763-1824) siyahi Amerika Birleşik Devletleri'nde bilinen ilk Afrikalı Amerikalı portre ressamı olmuş kendisiyle ilgili olarak kaynaklarda çok az kesin bilgi bulunmaktadır. Muhtemelen Batı Hint Adaları'nda doğmuştu ve Amerika'ya 1770'lerde Philadelphia sanatçısı Charles Willson Peale'nin ailesinin kölesi ya da sözleşmeli hizmetçisi olarak gelmiş gibi görünmektedir. Johnson sonunda özgürlüğüne kavuşmuş ve yaklaşık 1796'dan 1825'e kadar Baltimore' da çalışmıştı (Resim 4 ve 13).

Kendisine göre Johnson, resim konusunda bir "deha” olmuştu. Johnson, tek imzalı eseri olan Sarah Ogden Gustin (1798-1802 dolaylarında) dâhil olmak üzere seksenden fazla portre yaptı. Konuları, en zengin Baltimore ailelerinin üyelerinden, orta ve işçi sınıfı bireylere kadar uzanıyordu. Johnson'ın portreleri, karmaşıklığı halk sadeliğiyle birleştiren Peales'in sanatsal etkisini ve resmi eğitimden yoksunluğunu gösteriyordu (Hartigan, 1985).

Joshua Johnson, 1930'larda, Johnson'a on üç resim atfeden, hayatını ve kariyerini parça parça ve çoğu zaman çelişkili bilgilere dayanarak yeniden oluşturmaya çalışan Baltimorlu bir sanat tarihçisi olan J. Hall Pleasants tarafından yeniden keşfedildi. Sanatçı hakkında gündeme getirilen birçok soru arasında 1rk1, yaşamındaki önemli olayların tarihleri, adının yazılışı (Johnson veya Johnston) ve hayatıyla ilgili diğer önemli ayrıntılar vardı. Maryland Tarih Kurumu El Yazmaları Departmanı, ipotek belgeleri, hibe senetleri, vekâletname, satış senetleri ve ibrazlar gibi kişisel mülkiyet işlemlerinin kayıtları da dâhil olmak üzere üç cilt Baltimore ilçe mahkemesi menkul kıymet kaydı aldığında, spekülasyonların bir kısmı netlik kazanmıştı ve doğru kendisiyle ilgili olarak bilinen pek çok bilginin doğru olmadığı kanıtlanmıştı (Chotner, 1992: 225-226). 
Joshua Johnson, 1782'de özgürlüğünü kazandıktan sonra, 1796'dan 1824'e kadar Baltimore şehir rehberlerinde portre ressamı olarak kaydolmuştu. Sıklıkla Baltimore'da yaşadı. Eğitimine dair herhangi bir kayıt bilgisi edinilmemiştir (Bryan \& Torchia, 1996: 2-7).

Gilbert Stuart ise Erken Cumhuriyet Dönemi'nin en başarılı ve üretken Amerikan portrecilerinden birisiydi. Rhode Island yerlisi olan Gilbert Stuart (1755-1828), çağdaşlarının portre resmiyle ilgili fikirlerine katılmamıştı. Ticari potansiyelini sonuna kadar kullanmıştı. En çok George Washington portreleriyle tanınmış Stuart, Benjamin West'in yanında eğitim görmüş İngiltere'de portre ressamı olarak ünlenmişti. Buradaki sanatsal başarısına rağmen, abartılı yaşam tarzı nedeniyle finansal açıdan zorluk yaşamıştı.

Gilbert Stuart, West'in stüdyosunda eğitim alan koloni dönemi bir ressamdi. Stuart, (Resim 5) 1777'de Londra'ya, 1780'de Trumbull'a geldi. Connecticut'tan Ralph Earl, muhtemelen 1778'de Londra'ya geldikten sonra veya İngiltere'de geçirdiği yedi yıl boyunca Batı' da biraz eğitim aldı. Earl, 1785'te Connecticut'a döndü. Sonraki on beş y1l boyunca bu Eyaletin Batı kesiminde çok sayıda portre yaptı. Ayrıca, New Haven'dan Amos Doolittle'in gravürlerinin kaynağı olan Lexington ve Concord savaşlarının bulunduğu yerde dört resim yaptı. Bunlar, William Dunlap'ın Amerika Birleşik Devletleri'nde Tasarım Sanatının Yükselişi ve İlerleme Tarihi (1834) tarafından "Amerika'da yapılan belki de ilk tarihi resimler" olarak kabul edildi (Harris, 1966).

Gibbs-Channing-Avery portresi olarak adlandırılan bu Başkan Washington portresi, Vaughan grubu olarak bilinen on sekiz benzer çalışmadan biridir. Muhtemelen gerçek hayattan alınmış ve sonra diğerleri kopyalanmış olan bu türün ilki, aslında Philadelphia'da yaşayan Londralı bir tüccar ve Washington'un yakın bir arkadaşı olan Samuel Vaughan'a aitti. Rembrandt Peale'e göre 1795'te çizilen Stuart'ın bu orijinal portresi daha sonra Philadelphialı Joseph Harrison tarafindan 
satın alındı. Harrison'1n koleksiyonundayken, Rembrandt Peale onu birçok kez kopyaladı. Şu anda Metropolitan Sanat Müzesi'nde bulunan ve en eski ve en iyi kopyalardan biri olarak kabul edilen versiyon, Stuart'ın yakın arkadaşı Albay George Gibbs'e satıldı ve daha sonra Gibbs ailesine ulaştı (Gardner \& Feld, 1965).

Kuzey Amerika'nın İngiliz kolonilerinde doğan en yetenekli üç ressam Charles Willson Peale (1741-1827), Benjamin West (1738-1820) ve John Singleton Copley'den (1738-1815) yalnızca Peale, Devrim'den sonra Amerika'da kaldı. Queen Anne's County, Maryland'de doğdu ve saraçlık eğitimi aldı. 1760'larda Boston'da tanıştığı John Hesselius ve Copley gibi diğer sanatçıların çalışmalarını inceleyerek ressam oldu. Birkaç tüccar ve avukat, John Beale Bordley de dâhil olmak üzere, 17671769'da Peale'in West ile çalıştığı Londra'ya iki yıllık bir geziyi finanse etti. Londra'dayken İngiliz resim teorisine dalmış ve Amerika'ya döndükten sonra uzun yıllar West ile yazışmıştır (Miller, 1983-1991).

Peale, Maryland, Virginia ve Philadelphia'da portre ressamı olmuş ve 1776 'da ailesiyle birlikte buraya taşınmıştı (Resim 7). Devrim sirasında ve sonrasında Peale, sanatsal kariyerini "Whig" siyasetiyle birleştirdi. İngilizlere karşı verilen savaşlarda Pennsylvania milisleriyle birlikte görev yaptı ve subayların portrelerini yapmak için minyatür çantasını hep yanında taşıdığı belirtilmektedir.

1779'da Pennsylvania Yüksek Yürütme Konseyi, Washington'un (Pennsylvania Güzel Sanatlar Akademisi) ilk resmi portresi olan Princeton ve Trenton'daki zaferleri anan George Washington'un tam boy portresini yapması için onu görevlendirdi (Richardson, 1983).

Peale'nin Büyük Adamlar Galerisi fikri, onu sadece baş ve omuz bölgeleri olan "müze" portreleri yapmaya yöneltmiş; bu çalışmalarının ilki 1782'de tamamlamıştır. Peale birçok entelektüel ve siyasi liderin arkadaşıydı ve sonunda Washington, Thomas Jefferson, David 
Rittenhouse, Marquis de Lafayette ve Benjamin dâhil olmak üzere savaşın ve yeni cumhuriyetin birçok kahramanının resimlerini çizmişti. Kardeşi James, yeğeni Charles Peale Polk ve oğulları Raphaelle, Rembrandt ve Rubens Peale'i ressam olarak eğitti ve 1795'te Philadelphia'da tek halka açık sergisini düzenleyen ilk Amerikan sanatçılar topluluğu olan Columbianum'un kurucusu oldu (Miles, 1995: 112).

Peale'nin portresini yaptı̆g 1 Margaret Maryland, Anne Arundel County'deki London Town'dan William Strachan'ın kızıydı (Resim 7). 1772'de Maryland'in Batı Kıyısı'nda 1776'dan 1804'teki ölümüne kadar mali işler sorumlusu olarak görev yapan Thomas Harwood ile evlenmişti. Tarihsiz olmasına rağmen, bu eser muhtemelen Strachans'in evliliğinden önce yapılmıştı. Thomas Harwood'un eşlik eden portresi 1775 civarında yapılmıştır ve şu anda Delaware'deki Winterthur Müzesi koleksiyonundadir.

John Vanderlyn, (1775-1852) kim 1775'te Kingston, Ulster County, New York'ta, ressam Nicholas Vanderlyn ve onun ikinci eşi Sarah Tappan'ın oğlu olarak doğmuştur. Büyükbabası Hollandalı göçmen Pieter Vanderlyn olmuş ve saygın bir kurum olan "Kingston Academy"de eğitimini tamamladıktan sonra New York'a gitmiştir. Orada gravür üzerine sanat malzemeleri satan bir dükkânında çalışmıştır. Alexander ve Archibald Robinson'n Kolomb Resim Akademisi'nde sanat eğitimi almıştır (Resim 10).

New Yorklu Vanderlyn, bu ustaca otoportresini dört y1ldır yaşadığı Paris'te yaptı. Fransa'da okuyan ilk Amerika doğumlu ressamdı. Çalışma, Vanderlyn'in öğretmeni François-André Vincent'in 1800 Salonunda tuvali öven Neoklasik usta Jacques-Louis David'in etkisini gösteriyor (Mondello, 1990).

Vanderlyn kısa süre sonra, yirmi yıl boyunca kendisine maddi destek ve himaye sağlayan Aaron Burr'un dikkatini çekti. Burr, 
Philadelphia'daki Gilbert Stuart ile kısa bir süre çalışması için bir program yapt1 ve onu 1796 'da Paris'e gönderdi. Vanderlyn, Ecole des Beaux-Arts'a tarih ressamı ve portreci Francois-Andre Vincent ile kaydoldu. Louvre'daki Eski Ustaların eserlerini kopyaladı. Panoramik resme olan ilgisini keşfettiren Robert Fulton ile tanıştı (Oedell, 1981).

Vanderlyn 1800'de Amerika Birleşik Devletleri'ne döndü, burada bir dizi gravür için Niagara Şelaleleri'nin eskizlerini, New York ve Washington'da portre çalışmalarını yapmıştı. 1803'te yeni kurulan Amerikan Güzel Sanatlar Akademisi'ne antika heykel kalıpları temin etmek için Paris'e dönmüştü. Londra ziyareti sırasında Washington Allston ile tanıştı ve iki sanatçı daha sonra birlikte Avrupa'yı dolaşmış sonrasında. 1804'te Vanderlyn, Joel Barlow tarafından epik şiiri “The Columbiad" için örnek olarak kullanılmak üzere görevlendirilen ilk tarihi konusu olan Jane McCrea'nın Ölümü'nü (Wadsworth Atheneum, Hartford, Connecticut) resmini yapmıştı. Roma'da, "1808 Salonunda" Napolyon'un takdir ettiği ve altın madalya ile ödüllendirilen Kartaca Harabeleri Arasında güçlü Caius Marius'u (1807, San Francisco Güzel Sanatlar Müzeleri) yapmıştı.

Sanatçı ve mucit Samuel Finley Breese Morse, (1791-1872) Rahip Jedidiah Morse ve Elizabeth Ann Breese'nin en büyük oğlu olarak 1791'de Charlestown, Massachusetts'te doğmuştu. Morse'un entelektüel bakış açısı ve kültürel milliyetçiliğe gelecekteki bağlılığı, babasından miras aldığ Ortodoks Kalvinist ve Evanjelizm'den derinden etkilenmişti Yale Üniversitesi'ne devam ederken Connecticut Okulu'nun naif üslup karakteristiğinde portreler yapmaya başlamıştı. Mezun olduktan sonra Boston'a taşınmış ve Washington Allston'ın özel öğrencisi ve arkadaş1 olmuştu. Ona çizim, anatomi ve sanat teorisini içeren geleneksel bir akademik çalışma programını tanıtmıştı. Allston'ın teşvikiyle 1811'de Londra'ya gitmiş, Benjamin West ile tanışarak, Charles Robert Leslie ile arkadaş olmuş ve Royal Academy of Art'a öğrenci olarak kabul edilmişti. Morse'un ilk büyük resmi "The Dying Hercules (1812-1813, Yale 
Üniversitesi Sanat Galerisi, New Haven)", Akademi ressamları arasında revaçta olan neoklasik tarih resminde oldukça başarılı bir çalışma olarak kabul edilmişti.

İyimserlikle dolu genç ressam, kendisini profesyonel bir sanatçı olarak yetiştirme beklentisiyle 1815 'te Amerika'ya döndü. Sofistike olmayan kültürel atmosfer, onun özlemlerine elverişli değildi ve Morse, New England, Charleston, Güney Carolina ve New York'ta faal olan gezici bir portreci olarak ekonomik yönden yetersiz bir hayata başladı (Larkin, 1954: 77) (Resim 8).

Kamusal eğlence için bir resmi gezi olarak düşünülen Temsilciler Meclisi (1822-1823, The Corcoran Gallery of Art, Washington, D.C.) resmi bir eleştiri ve finansal bir başarısızlık olduğunda büyük bir hayal kırıklığı yaşadı. Morse'un azmi nihayet 1824'te, Fransız kahramanı Amerika'da zafer turundayken tam boy portre "The Marquis de Lafayette"i (1825-1826, New York Şehri) yapmak için son on yılın en prestijli çalışması ödülünü kazanmasıyla ödüllendirildi. Bu önemli portrenin başarılı bir şekilde tamamlanması, Morse'a yıllardır aradığ 1 tanınmayı ve profesyonel saygınlığı kazandırdı. Sonunda bir sanatçı olarak kariyerinin zirvesini belirledi (Kloss, 1988).

1826 'da sanatçıların hakları adına eğitimli, etkili ve yorulmak bilmeyen bir savaşçı olan Morse, yeni prestijini neredeyse ölmekte olan Amerikan Sanat Akademisi'nden ayrılan ve İlerici Ulusal Tasarım Akademisi'ni kuran bir grup genç sanatçıya liderlik etmek için kullanmıştı.1845'e kadar ilk başkanı olarak burada görev yaparak, öncelikli olarak sanat eğitimine adanmış bu yeni örgütün kuruluşu, doğrudan Amerikan sanatının gelişmesine yol açmıştı. Daha sonra ise yeni nesil ressam ve heykeltıraşlar, yıllık sergilerinde ilk kez sahneye çıkmıştılar. 
1826 'da Morse, “New York Athenaeum"da Amerikan toplumunda sanatın ilerlemesini savunduğu bir dizi dört önemli konferans vermişti.

1829 'da üç yıllık büyük bir Avrupa turuna çıkmış ve burada Fransa ve İtalya müzelerinde eski ustaların eserlerini çalışıp kopyalamıştı. Bu dönem, 1832'de New York'a döndükten sonra Amerikan kültürünü geliştirmeyi umduğu Avrupa sanatının resimli bir özeti olan büyük Louvre Galerisi (1832-1833, Terra Amerikan Sanat1 Müzesi, Chicago) ile doruğa ulaşmıştı.

Yaptığı bu resim beğenilip etkili olmasına ve aydınlar arasında kabul görmesine rağmen, resim Amerikan halkı tarafından beğenilmeyip başarısız bulundu. Morse, 1837'de Kongre Kamu Binaları Komitesi'nin "Capitol Rotunda" için bir duvar resmi yapması amaciyla kendisini görevlendirmemeye karar vermesiyle daha da aşağılanmıştı (Staiti, 1989: 113).

Bir sanatçı olarak Morse, 19. yüzyıl Amerikan sanatının üslup gelişimi üzerinde büyük bir etki yapmamış fikirleri, sanatı, yalnızca kültürel seçkinlerin ilgisini çekmiştir. Ölümünden çok önce Morse'un telgraf icad1, ressam olarak ününü gölgede bırakmıştı ve ancak 1932'de Metropolitan Sanat Müzesi'nde yaptığı eserinin retrospektif sergisinden sonra sanatına olan ilgi yeniden canlanmıştı. Romantik "Lafayette" portresi haricinde, en iddialı çalışmaları, kabullenmeyen bir halkın önünde başarısız olmuştu. Tarihi konuları resimleyerek geçimini sağlayamadığ i için portreciliğe zorlanmıştı ve bu resimlerin birçoğu göz ardı edilebilecek kalitede olmuştu. Morse, Amerika'da sanatı ilerletmek için aslında çok şey yapmıştı, National Academy of Design'ın kurucusu ve ilk başkanı olmuştu.

Rubens Peale, kardeşi Rembrandt Peale (1778-1860) tarafindan, bir doğa bilimci olarak ilgi alanlarını yansıtan bir sardunya olan çalışmasını bir nesneyle canlandırmıştır. Resimde görülen bitkinin 
Amerika'da yetişen ilk sardunya olduğu belirtilmektedir. Amerika'da o zamana kadar sardunyalar egzotik ve ender bir tür olarak görülmüştü. Figürün çalışkan bir kişiliğinin olması gözlük ile belirtilmiştir. Ayrıca, gözlük Rubens'in zayıf görüşüne gönderme de yapmaktadır. 1810'da Philadelphia Müzesi'nin müdürü olmuştur. Charles Willson Peale tarafindan 1784'te ülkenin ilk halk müzesi olarak kurulmuştur. Burası resimlerini sergilemek için tasarlanmış bir galeriydi, ama aynı zamanda kâşifler tarafindan toplanan egzotik örneklerden oluşan bir koleksiyonla doğa tarihini de kapsamıştır. Rubens daha sonra Baltimore'da bir şube olan Peale Müzesi'nin müdürü olarak görev yapmıştır (Resim 16).

Thomas Sully (1783-1872), 1801'de 20 yaşında profesyonel bir ressam olarak Boston'da Gilbert Stuart'in yanında üç hafta portre resim eğitimi almıştı. Kardeşi Lawrence ile Virginia'da bir süre kaldıktan sonra Sully, New York'a taşınmış, 1806'da hayatının geri kalanında yaşadığı Philadelphia'ya yerleşmişti. 1809'da Sully, resim kariyerini Büyük Britanya'da kuran Amerikalı Benjamin West'in yanında dokuz aylık eğitim için Londra'ya gitmişti.

Sadece en zengin aileler, iki metre uzunluğundaki Arplı Leydi gibi büyük bir portreye sahip olabilmişti. Portre, masraflarına ek olarak, geniş duvarları ve yüksek tavanları olan geniş bir ev de gerektirmişti. Eliza Ridgely, Philadelphia'daki bir yatılı okulda on beş yaşında bir öğrenciyken babası, portresini yapması için Philadelphia merkezli Thomas Sully'yi tutmuştu. O zamanlar Sully, çağının en popüler ve üretken portrecilerinden biriydi ve yeteneği, müşterilerini idealleştirme ve övme yeteneğindeydi. Burada figür (Resim 15), arpiyla adeta bir tanrıça gibi görünür, figür uzamış ve zarif bir konuma dönüşmüştür. Resim tamamlandığında, Philadelphia Güzel Sanatlar Akademisi'nde “Arplı Genç Kadın” olarak kısa bir süre sergilenmiş ve ardından son varış yeri olan ailenin Baltimore dişındaki Towson, Maryland'deki evine ulaşmıştı.

Uludağ Üniversitesi Fen-Edebiyat Fakültesi Sosyal Bilimler Dergisi Uludağ University Faculty of Arts and Sciences Journal of Social Sciences

Cilt: 22 Sayı: 41 / Volume: 22 Issue: 41 
Eliza Ridgely, bu portrede sahnelendiği gibi figür gerçekten arp çalıyordu; onun arpı, babası tarafından Londra'dan ithal edilen ender bir enstrümand1. O zamanlar Ridgely ailesi, George Washington'a rakip olan ABD'deki en zenginleri arasındayd. Önceki nesil Ridgelys, Devrim Savaş1 sırasında vatanseverler için toplar üreterek zenginleşmişti. Sonraki nesiller tarım, hayvancılık ve ticari faaliyetlerde başarılı olmuştu.

George Catlin (1796-1872) Amerikan Yerlileri portrelerinde uzmanlaşmış bir avukat, ressam, yazar aynı zamanda gezgin olarak ünlenmiştir.

Catlin, Yerli kabilelerin özerkliğini ihlal eden ABD yasalarının yaşamı boyunca geçişi nedeniyle Yerli Amerikalıların yok edilmesinden korkmuştu. $\mathrm{Bu}$, onu, yaşam tarzları tehdit altında olan insanları belgelemek için orta batı ve ovalardaki elliden fazla kabileyi ziyaret etme görevine itmişti. Günümüz koşullarıyla değerlendirildiğinde bu durum bazı açılardan Kolonileşme olarak yorumlanabilmektedir. Aynı zamanda, Catlin'in sanatı, 19. yüzyılda yaygın olarak dolaşan Amerikan Yerlilerinin ırkçı fikirlerine inanan, fotoğraftan önceki dönemde, belirli Yerli insanların ve onların kültürlerinin önemli bir kaydını sunmaktadır. Kâş̧if William Clark bu durumu şu şekilde belirtmiştir: "Bay Catlin'in çoğu bana tanıdık gelen ve benim huzurumda resmi yapılan Kızılderililerin portrelerinden oluşan koleksiyonunu gördüm... Orijinalleriyle en çarpıcı benzerliği taşıyan benzerlikler kolayca tanınır ve kostümlerinin aslına uygun temsilleri." 20. yüzyılda bu eserler önemli belgeler olmanın yanı sıra sanat eseri olarak yeniden değerlendirilmeye başland1. Catlin'in bu eseri yaptı̆̆ dönemde bu kabile ile ilişkili bölgede olduğu tahmin edilmektedir (Resim 14).

William Matthew Prior, (1796-1872) (Resim 1) Bath, Maine'de doğmuş daha çok portreleriyle tanınan ancak bazı manzara çalışmaları da olan Amerikalı bir başka ressamdır. Kariyerinin ilk yıllarında iş aramak 
için New England çevresinde şehirden şehire seyahat etmişti. Özellikle çocukların stilize, düz portrelerinde uzmanlaşmıştı.

Daha natüralist, eserler verebilmesine rağmen, resimlerinin çoğunu soyut ve düzleştirilmiş tarzda yapmıştır. Çünkü bu şekilde daha hızlı çalışabiliyordu ve daha uygun fiyatla müşterilerinin siparişlerini üretebiliyordu. 1831'de "Maine Inquirer"da "düzgün bir resim isteyen kişilerin, dörtte bir fiyata sahip olabileceğini" dair ilan verdi. 1841'de Prior, çok başarılı kariyerinin sonuna kadar kaldığı Boston'da yaşadı (Johnston, 1979: 20-23, 66).

Sanatçı, 1829'da bir ressam ailenin kızı olan Rosamond Clark Hamblin ile evlendi. Yaklaşık 1846'da Prior, 1873'te ölümüne kadar yaşadığı ve çalıştığı Doğu Boston'daki 36 Trenton Caddesi adresine verdiği isim olan "Painting Garret"e taşındı. Sipariş aramak için Baltimore kadar güneye gitti; fakat resim gezilerinin çoğu New England'da yoğunlaştı (Little, 1948: 44-48).

George Peter Alexander Healy, (1813-1894) 15 Temmuz 1813'te, İrlandalı bir göçmen ve bir ticaret gemisinin kaptanı olan William Healy ile karısı Mary Hicks'in beş çocuğundan ilki olarak Boston'da doğdu. Healy sanata erken yaşata ilgi gösterdi. 1830'da kendi kendini yetiştiren ressam, ailesini geçindirmeye yardımc1 olmayı umduğu bir portre stüdyosu açtı. İlk başta siparişleri az olmasına rağmen, genç Healy, kendisine mesleğini resim yapmak olarak tavsiyede bulunan Thomas Sully'den önemli bir destek aldı. 1831'de Boston toplumunun lideri Bayan Harrison Gray Otis ona portresini yapma izni verdiğinde ve yeteneklerini diğer potansiyel müşterilere de tavsiye ettiğinde serveti de artt1 (Lewison, 1968: 54-59, 69-73).

1834 'te Healy, Baron Antoine - Jean ile çalıştığı Fransa'ya gitti. Bir yıl sonra İtalya'yı dolaşarak, kısa süre sonra Londra toplumuyla tanışmasını sağlayan Lady ve Sir Arthur Faulkner ile müze ve kiliseleri ziyaret etti (Healy, 1970). 
Healy'nin 1839 'da Louisa Phipps ile tanıştı̆̆ ve evlendiği yer İngiltere'deydi. Çift, Healy'nin uzun ve mutlu bir evliliğin ve başarılı bir kariyerin başlangıcına başladığı Paris'e yerleşti. Diplomatik ve nazik tavrı, ona Avrupa ve Amerika Birleşik Devletleri'nde muazzam bir başarı getirdi (Kelly vd., 1996: 298).

Yetenekli olduğu kadar üretken de olan Healey 1867 'de altı yüzden fazla portre üretmişti (Resim 11). Çalışmaları arasında, Healy ve ailesiyle yakın bir dostluk geliştiren Papa Pius IX ve Romanya Kraliçesi Elizabeth gibi ünlü figürlerin saygın, heybetli portreleri de bulunmaktadır.

Eastman Johnson (1824-1906) uzun yıllar Amerika Birleşik Devletleri'nin en önde gelen tür ressamı olup, kendi kuşağının yurtdışında kapsamlı eğitim alan ilk Amerikalı sanatçıları arasındaydı. Yapıtları, geleneksel, yerli konuları daha gelişmiş teknik ve anlatımla birleştirerek iki nesil için önemli bir bağlantı görevi görüyordu (Hills, 1977) (Resim 12).

Johnson, 1824'te Maine, Lovell'de doğmuş, ancak yakınlardaki Fryeburg'da büyümüştür. 1834'te ailesi, babasının eyalet yönetiminde yer aldığı Augusta'ya taşındı. Boston'da bir litografi dükkânında kısa bir süre çalıştıktan sonra on sekiz yaşında pastel boya portre stüdyosu açtı. Yaklaşık iki yıl sonra, ünlü kişilerden oluşan bir galeri inşa etme umuduyla, Dolly Madison ve John Quincy Adams gibi seçkin ulusal figürlerin siyah beyaz resimlerini aldığ 1 Washington, D.C.'ye taşındı. 1846 'da Boston'a döndü ve burada Henry Wadsworth Longfellow'un ailesinden oldukça fazla destek aldı (Baur, 1940).

Sanat çıraklı̆g 1849 'da Almanya'nın Düsseldorf kentine gittiğinde başladı ve o şehrin akademisinde çizim konusunda sıkı bir eğitim almıştı. Bununla birlikte, Emanuel Leutze'nin resme yoğunlaştığ 1 stüdyosunda geçirdiği zaman daha değerliydi. 1851'de Universal Exposition'1 görmek için Londra'ya gitmişti. Daha sonra üç yıldan fazla 
bir süre kalacak şekilde Lahey'e taşındı. Bir Amerikalı sanatçı için Lahey'de uzun süre kalması alışılmadık bir Ancak görünüşe göre, zengin Amerikan büyükelçisi August Belmont'un himayesinin yanı sıra Hollandalı eski ustalardan da çok ilham almıştır. Avrupa eğitimi, annesinin $1855^{\prime}$ te ölümünden önce Paris'teki Thomas Couture stüdyosunda geçirdiği birkaç ayla sona ermişti (Philadelphia Museum of Art, 1928).

Margaret Maryland, Anne Arundel County'deki London Town'dan William Strachan'ın kizıydı (Resim 7). 1772'de Maryland'in Batı Kıyısı'nda 1776'dan 1804'teki ölümüne kadar mali işler sorumlusu olarak görev yapan Thomas Harwood ile evlenmişti. Tarihsiz olmasına rağmen, bu eser muhtemelen Strachans'ın evliliğinden önce yapılmıştı. Thomas Harwood'un eşlik eden portresi 1775 civarında yapılmıştır ve şu anda Delaware'deki Winterthur Müzesi koleksiyonundadır

John Singer Sargent (1856-1925), Yaldızlı Çă̆'da (Mark Twain tarafından 1873 tarihli kitabında Gilded Age tarafından icat edilen terim) portreci olarak meşhur bir kariyere sahipti. $\mathrm{Bu}$, dönem zengin bir yaşam ve kişisel alanlarda çok büyük siyasi etkiye sahip birkaç kişinin servet biriktirdiği bir dönem olarak bilinmektedir. Sargent ve Townsends, Avrupa'da hayattan zevk alan ve uzun süreli kalışları olan uluslararası bir göçmen Amerikalılar ağının parçası olmuşlardır. Bu çalışma muhtemelen New York merkezli Townsends'in bir evi olduğu ve Sargent' in 1874'ten Londra'ya taşındığı 1886'ya kadar yaşadığı Paris'te yapılmıştı. Hayatının çoğunu yurtdışında geçirmişti.

12 yaşındaki bu genç kadın, Sargent'ın bir arkadaşının yedi çocuğundan birisi olmaktadır. İnce detaylardan ziyade geniş firça darbeleriyle spontane bir şekilde boyanmış olan eser, sanki Beatrice Townsend onunla portrede olmak için küçük bir köpeği almaya karar vermiş gibi anlık görüntü kalitesine sahip durmaktadır. Hareketin ve pozun rahatlığı gerçek ve sıcak görünmektedir. Kızın bakışları doğrudan 
ve kendinden emin, izleyiciye Beatrice'nin ayrıcalıklı hayatına bir göz atma imkânı sunmaktadır (Resim 18).

Amerika'nın ilk siyahi ressamlarından olan Henry Ossawa Tanner, (1859-1937) 1859'da Pittsburgh'da doğmuş, Afrika Metodist Piskoposluk Kilisesi'nde gelecekteki bir piskopos olan Rahip Benjamin Tucker Tanner ve eski bir köle olarak yeraltı demiryolunda çalışırken kaçan Sarah Tanner'ın beş çocuğundan ilki olarak dünyaya gelmişti. Amerika'nın siyahi ressamlarının içinde önemli bir yere sahiptir. Oğullarının alışılmadık ikinci adı, kölelik karşıtı John Brown’un kölelik karşıtı kampanyasını başlattığı Kansas, Osawatomie kasabasının adından gelmektedir. Aile 1868'de Philadelphia'ya yerleşmiş, 1879'da Tanner, Thomas Eakins'in yönetiminde eğitim aldığı Pennsylvania Güzel Sanatlar Akademisi'ne kaydolmuştur. Akademi'de ve Philadelphia Sanatçılar Topluluğu'nda çalışmalarını sergilemeye başlamış, 1889'da Atlanta, Georgia'da bir fotoğraf stüdyosu açmıştı.

$\mathrm{Bu}$ fotoğraf işi başarısız olmasına rağmen, genç sanatçı, Clark Üniversitesi'nde çizim öğretmesi için ayarlanan Joseph Crane Hartzell adlı Metodist Piskoposluk Kilisesi'nde bir piskoposla tanışmıştı. 1890’da Hartzell, Cincinnati' de Tanner'ın çalışmalarının bir sergisini düzenlemiş ve tabloların hiçbiri satılmadığında, kendisi ve eşi onları satın alarak, Tanner'a Avrupa'da bir eğitim görmesi için maddi destek sağlamıştır (Resim 3).

1891 'de Tanner Paris'e gitti ve “Academie Julian”da Jean-Joseph Benjamin Constant ve Jean-Paul Laurens' in yanında çalışmaya başladı. Paris, onu yalnızca sanat eğitimi alabileceği bir yer olarak değil, doğduğu ülkede yaşadığı 1rkçı önyargılardan arınmış daha liberal bir atmosfer sağladığı için de etkilemişti (Bearden \& Henderson, 1993: 78-109).

Tanner kısa süre sonra Amerikan Sanat Öğrencileri Kulübüne katıldı ve Fransa'daki ilk yaz mevsimini Pont-Aven, Brittany'deki sanatçı topluluğuyla geçirdi. Tanner'ın konu seçimi, ırksal kimliğinin 
artan bilincinden etkilenmiş ve 1893 'te Amerika'ya yaptığ 1 bir gezi sırasında Chicago'daki Dünya Afrika Kongresi'nde "The American Negro in Art” başlıklı bir makale sunmuştu. Sanatta zencilerin onurlu ve sempatik tasvirlerini yaratma konusunda bu dönemdeki endişesi The Banjo Lesson (1893, Hampton University Museum, Virginia) tarafindan örneklendirilmiştir (Mathews, 1969).

Araştırmada kullanılan son portre (Resim 17) çalışmasında, siyahi bir adamın nadir bir erken Amerikan portresini göstermektedir. Sanatçının ve müşterinin isimleri bilinmese de resim birkaç ipucu sağlamaktadır. Açık pencereden, nehir geçen bir vapur ve arkasındaki çardaklar ve ormanları görmek mümkündür. Gemi, Hudson Nehri üzerinde Albany ve New York City arasında seyahat eden ve geziyi dokuz saatte tamamlayarak rekorlar kıran bir yolcu vapuru olan New Philadelphia'dır. Afrikalı Amerikalıları görevli ve garson olarak istihdam eden ilk ticari yolcu hatlarından biriydi ve resimde görülen üniformalı adam gururla kendisini gemi hattıyla ilişkilendirmektedir. O sırada Connecticut'ta yapılan bir tür ahşap sandalye olan Hitchcock sandalyesine oturmaktadır. Bu şirket günümüzde de hâlâ faaliyetlerine devam etmektedir. Beyefendi eliyle yelek hareketine dikkat edildiğinde aynı pozun Robert Feke'nin daha önceki bir portresinde de bulunduğu fark edilmiştir. 


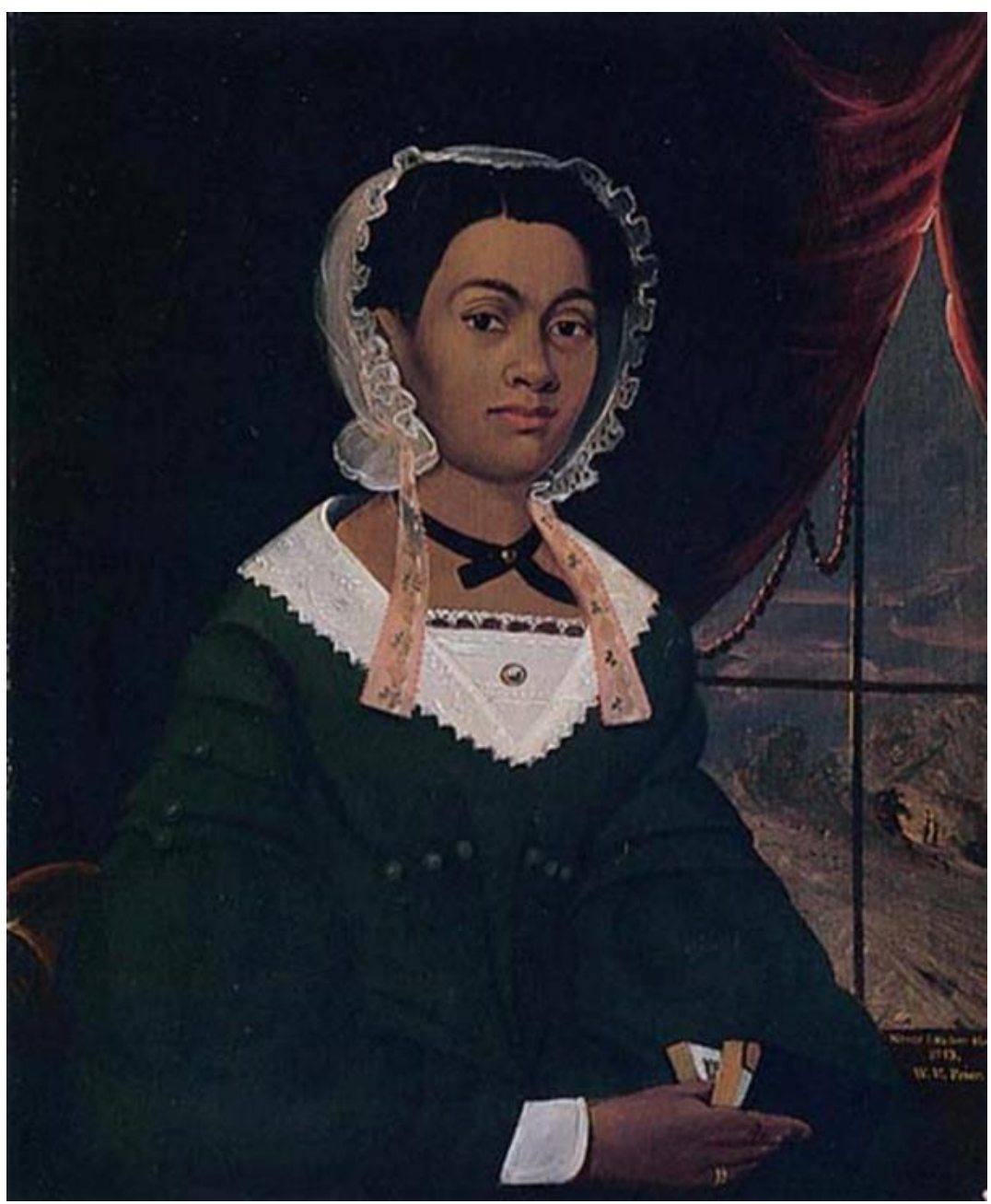

Görsel 1: William Matthew Prior Bayan, Nancy Lawson, $1843^{1}$

\section{1 https://folkartmuseum.org/exhibitions/artist-and-visionary-william-matthew-prior- revealed/}

Uludağ Üniversitesi Fen-Edebiyat Fakültesi Sosyal Bilimler Dergisi Uludağ University Faculty of Arts and Sciences Journal of Social Sciences Cilt: 22 Sayı: 41 / Volume: 22 Issue: 41 


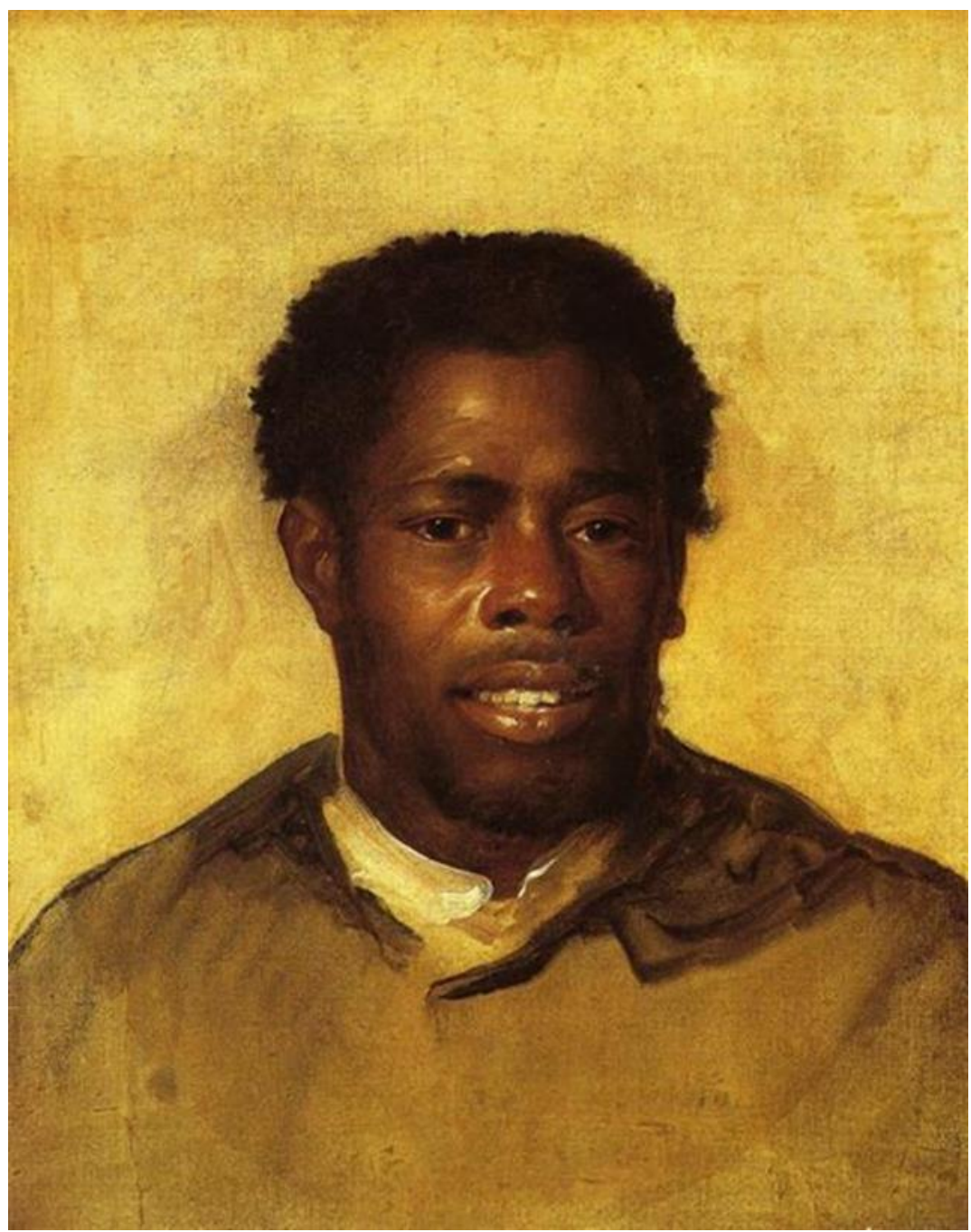

Görsel 2: John Singleton Copley Siyahi Bir Portre Çalışması, $1777^{2}$

${ }^{2}$ https://www.dia.org/art/collection/object/head-negro-41297

Uludağ Üniversitesi Fen-Edebiyat Fakültesi Sosyal Bilimler Dergisi Uludağ University Faculty of Arts and Sciences Journal of Social Sciences Cilt: 22 Sayl: 41 / Volume: 22 Issue: 41 


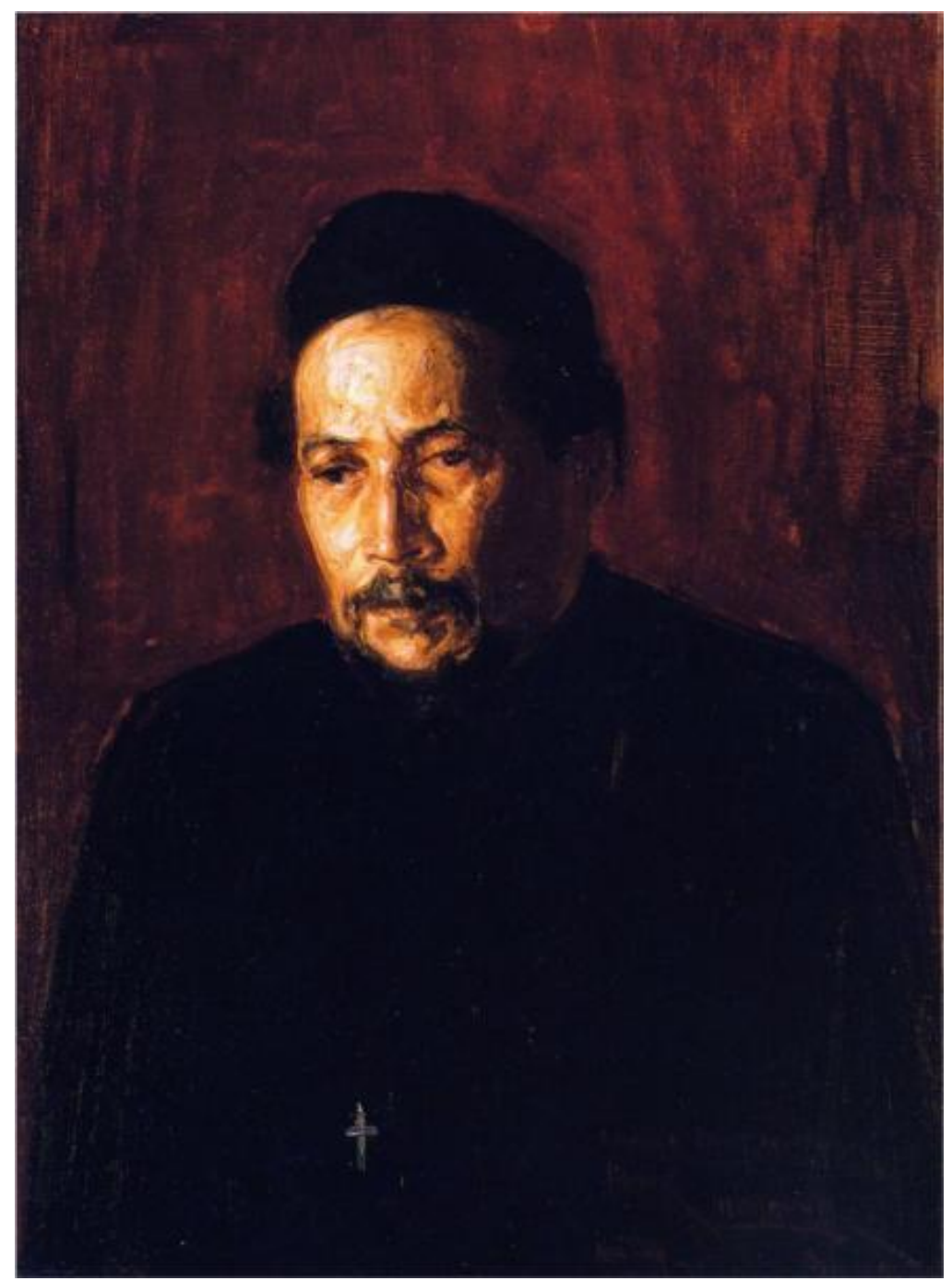

Görsel 3: Henry Ossawa Tanner, Piskopos, Benjamin Tucker Tanner, $1897^{3}$

${ }^{3}$ https://americanart.si.edu/artist/henry-ossawa-tanner-4742

Uludağ Üniversitesi Fen-Edebiyat Fakültesi Sosyal Bilimler Dergisi Uludağ University Faculty of Arts and Sciences Journal of Social Sciences Cilt: 22 Sayl: 41 / Volume: 22 Issue: 41 


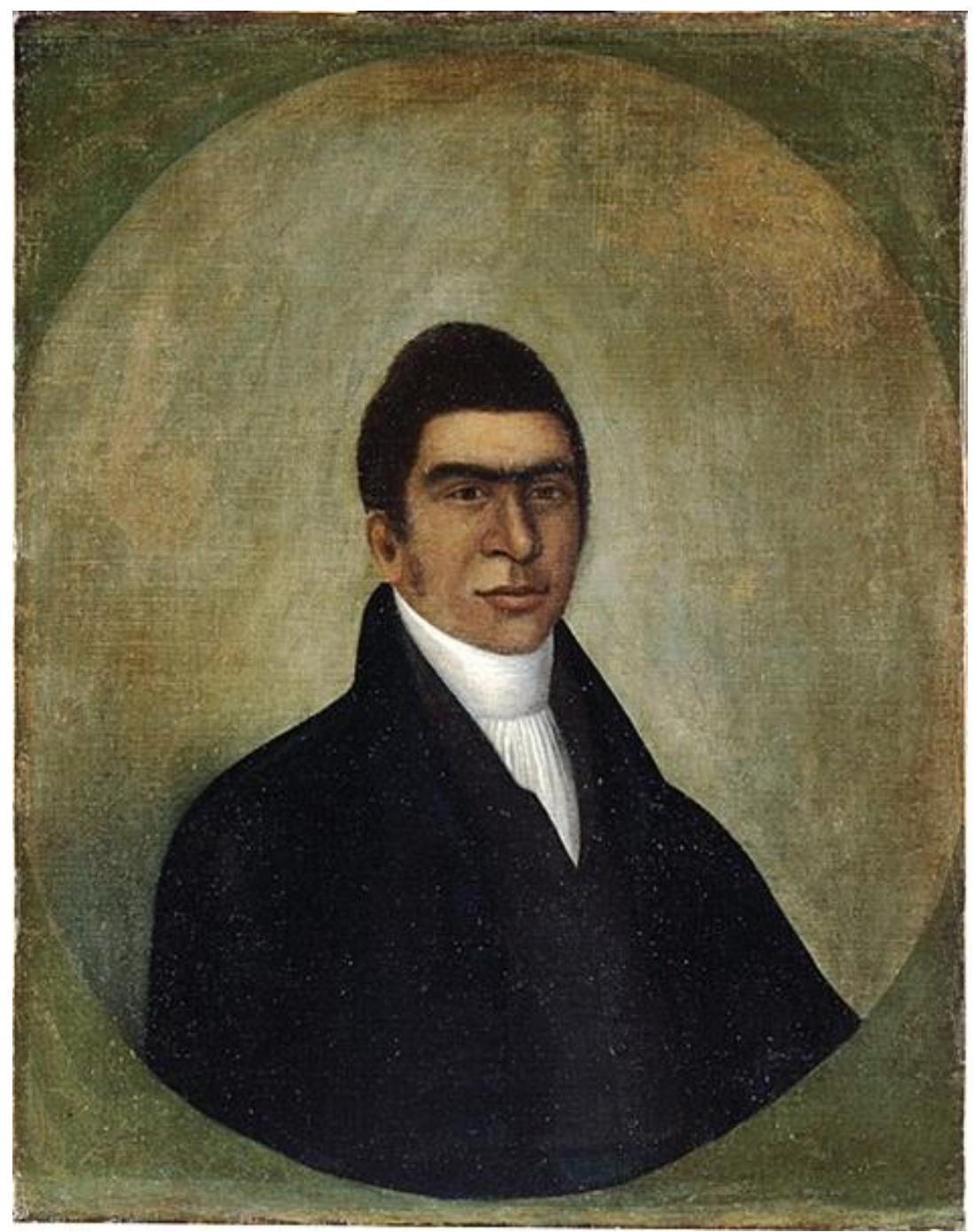

Görsel 4: Joshua Johnson, Portrait of a Man, $1805^{4}$

\section{${ }^{4}$ https://artmuseum.bowdoin.edu/objects-1/info/5625}

Uludağ Üniversitesi Fen-Edebiyat Fakültesi Sosyal Bilimler Dergisi Uludağ University Faculty of Arts and Sciences Journal of Social Sciences Cilt: 22 Sayl: 41 / Volume: 22 Issue: 41 


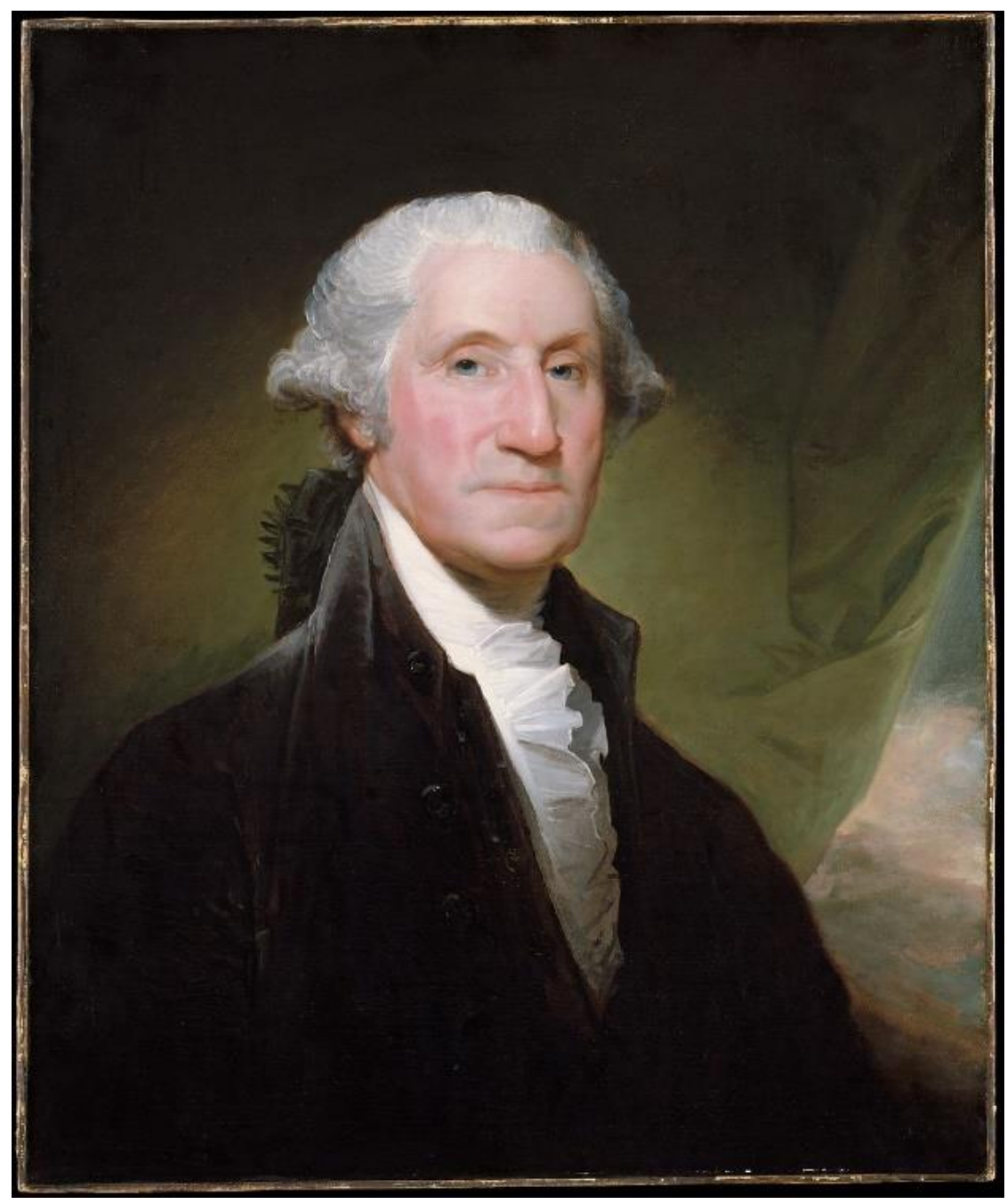

Görsel 5: Gilbert Stuart George Washington, Amerika Birleşik Devletlerinin 1. Başkanı, $1795^{5}$

\section{${ }^{5}$ https://www.metmuseum.org/art/collection/search/16584}

Uludağ Üniversitesi Fen-Edebiyat Fakültesi Sosyal Bilimler Dergisi Uludağ University Faculty of Arts and Sciences Journal of Social Sciences Cilt: 22 Sayl: 41 / Volume: 22 Issue: 41 


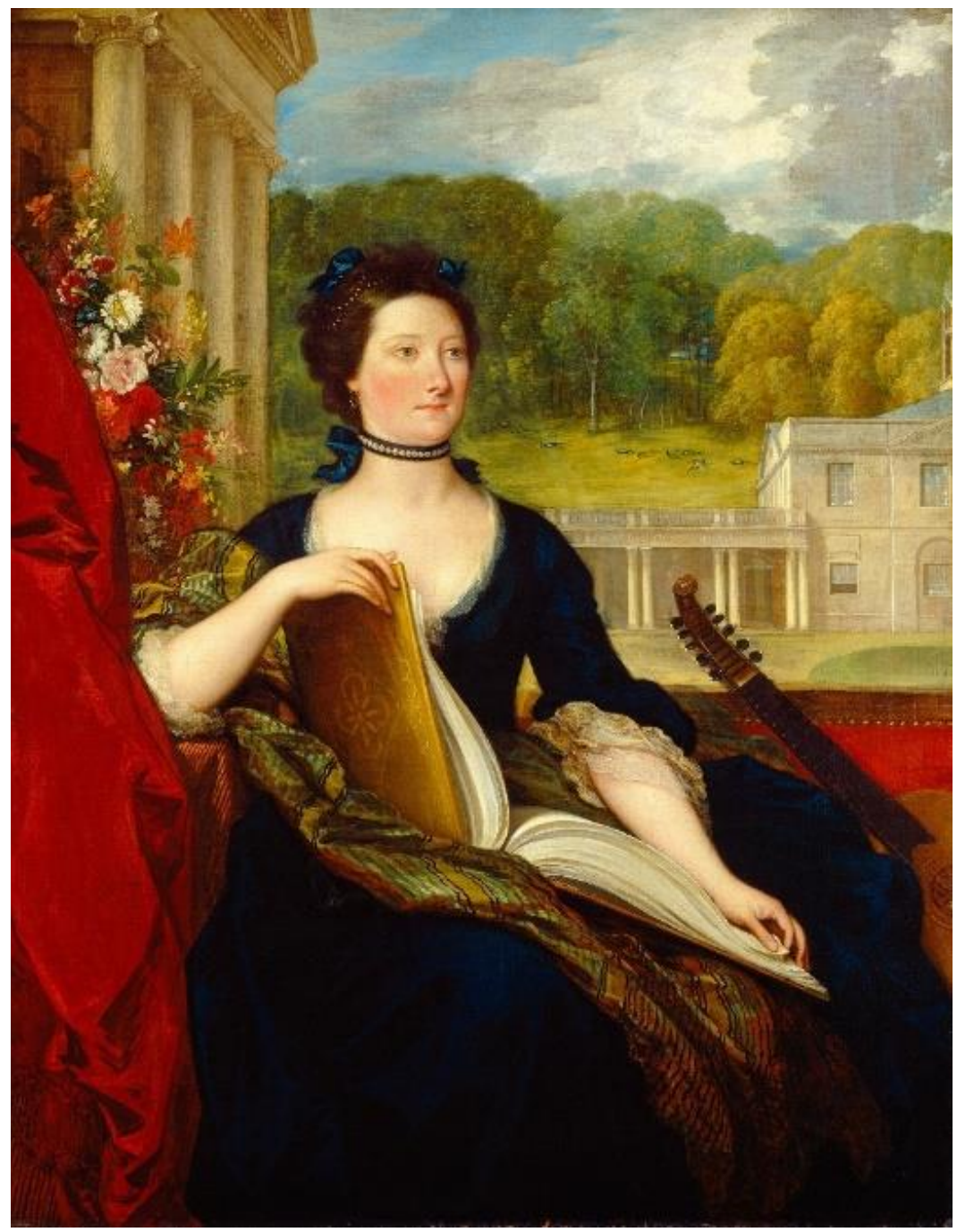

Görsel 6: Benjamin West, Maria Hamilton Beckford, $1799^{6}$

${ }^{6}$ https://www.nga.gov/collection/art-object-page.34071.html

Uludağ Üniversitesi Fen-Edebiyat Fakültesi Sosyal Bilimler Dergisi Uludağ University Faculty of Arts and Sciences Journal of Social Sciences Cilt: 22 Sayl: 41 / Volume: 22 Issue: 41 


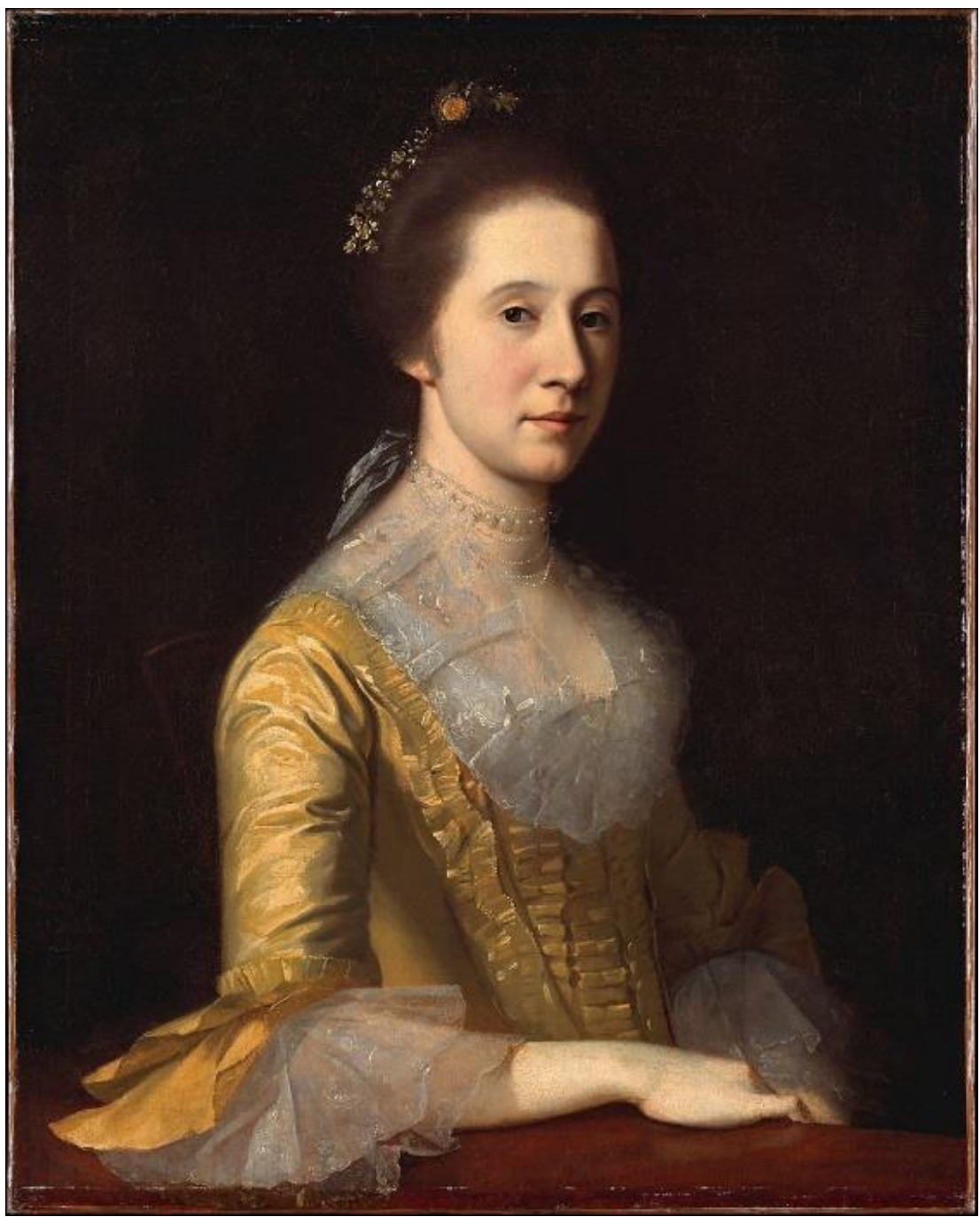

Görsel 7: Charles Willson Peale, Margaret Strachan, $1771^{7}$

\section{${ }^{7}$ https://www.metmuseum.org/art/collection/search/11710}

Uludağ Üniversitesi Fen-Edebiyat Fakültesi Sosyal Bilimler Dergisi Uludağ University Faculty of Arts and Sciences Journal of Social Sciences Cilt: 22 Sayl: 41 / Volume: 22 Issue: 41 


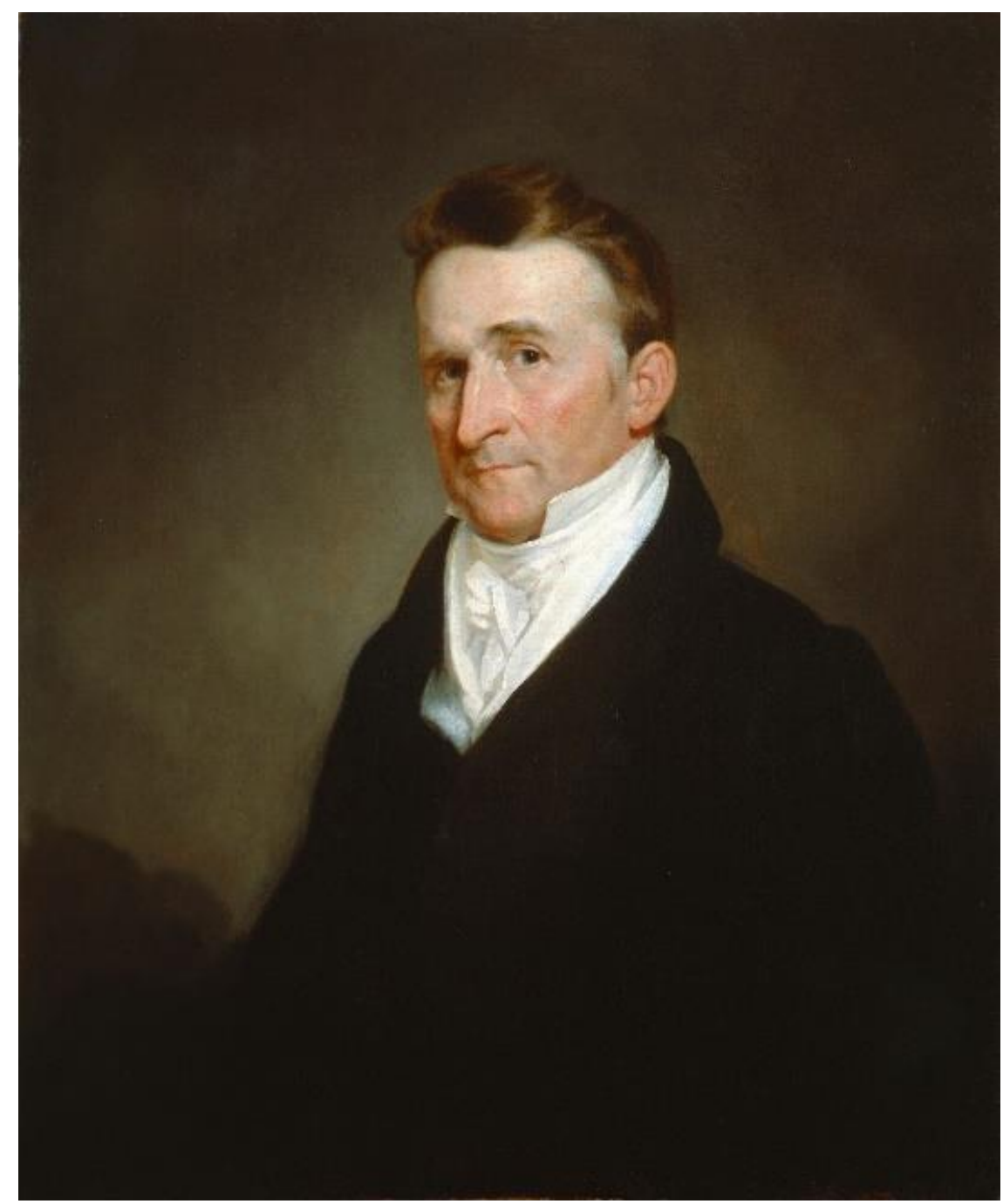

Görsel 8: Samuel F. B. Morse, Eliphalet Terry, $1824^{8}$

${ }^{8}$ https://www.nga.gov/collection/art-object-page.60790.html\#bibliography

Uludağ Üniversitesi Fen-Edebiyat Fakültesi Sosyal Bilimler Dergisi Uludağ University Faculty of Arts and Sciences Journal of Social Sciences Cilt: 22 Sayl: 41 / Volume: 22 Issue: 41 


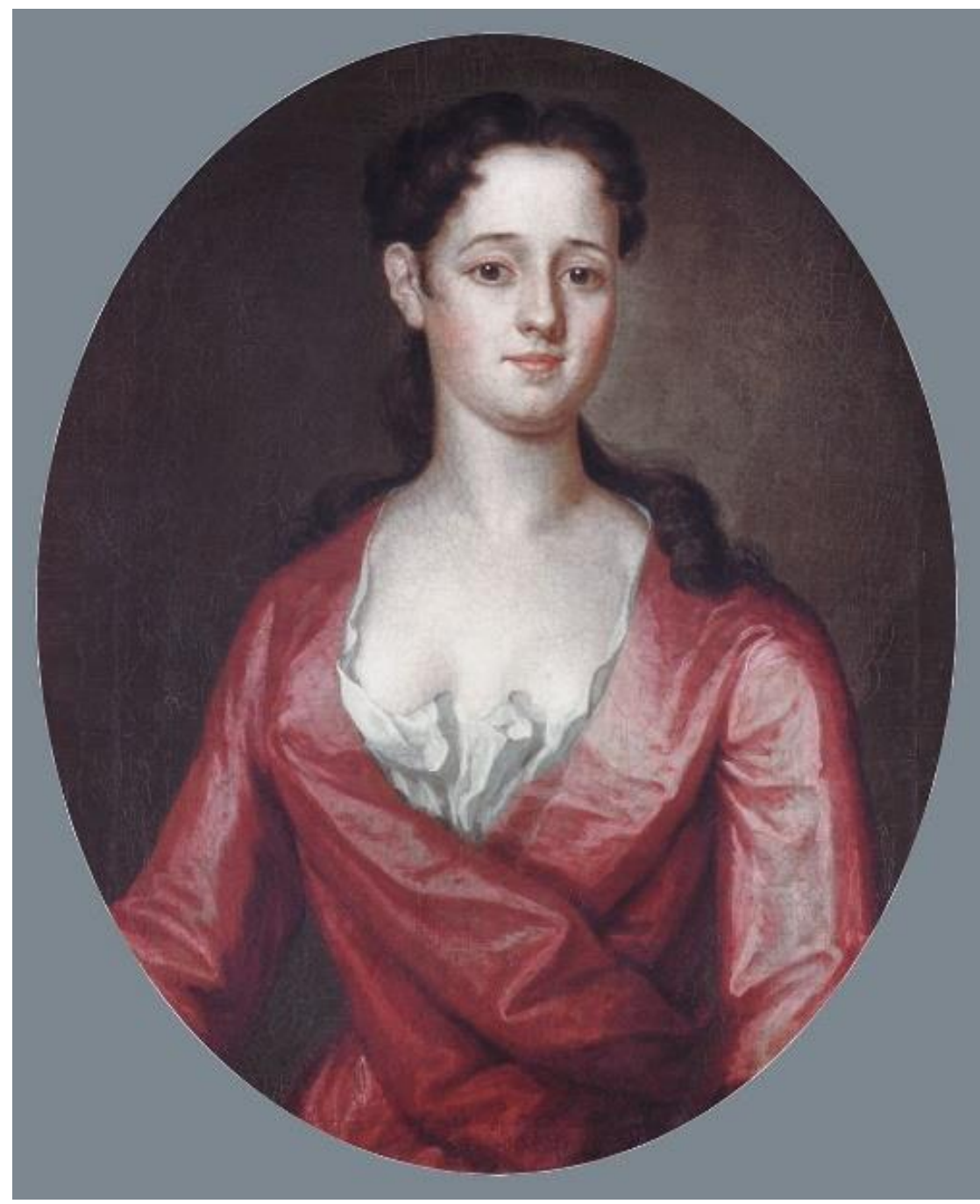

Görsel 9: John Smibert, Hannah Pemberton, $1734^{9}$

\section{${ }^{9}$ https://collections.britishart.yale.edu/catalog/tms:1057}

Uludağ Üniversitesi Fen-Edebiyat Fakültesi Sosyal Bilimler Dergisi Uludağ University Faculty of Arts and Sciences Journal of Social Sciences Cilt: 22 Sayl: 41 / Volume: 22 Issue: 41 


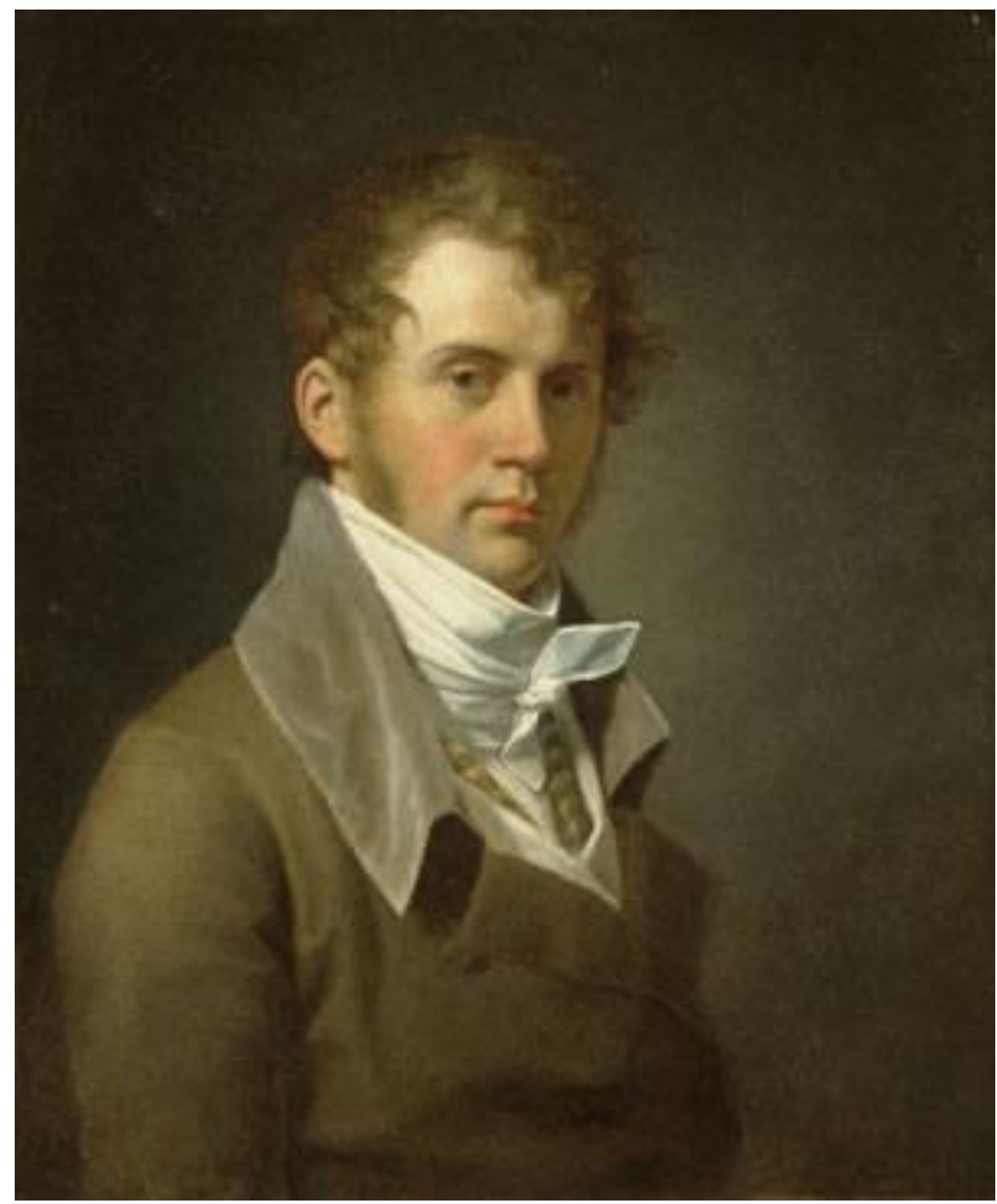

Görsel 10: John Vanderlyn, Otoportre, $1800^{10}$

${ }^{10}$ https://www.metmuseum.org/art/collection/search/13053

Uludağ Üniversitesi Fen-Edebiyat Fakültesi Sosyal Bilimler Dergisi Uludağ University Faculty of Arts and Sciences Journal of Social Sciences Cilt: 22 Sayı: 41 / Volume: 22 Issue: 41 


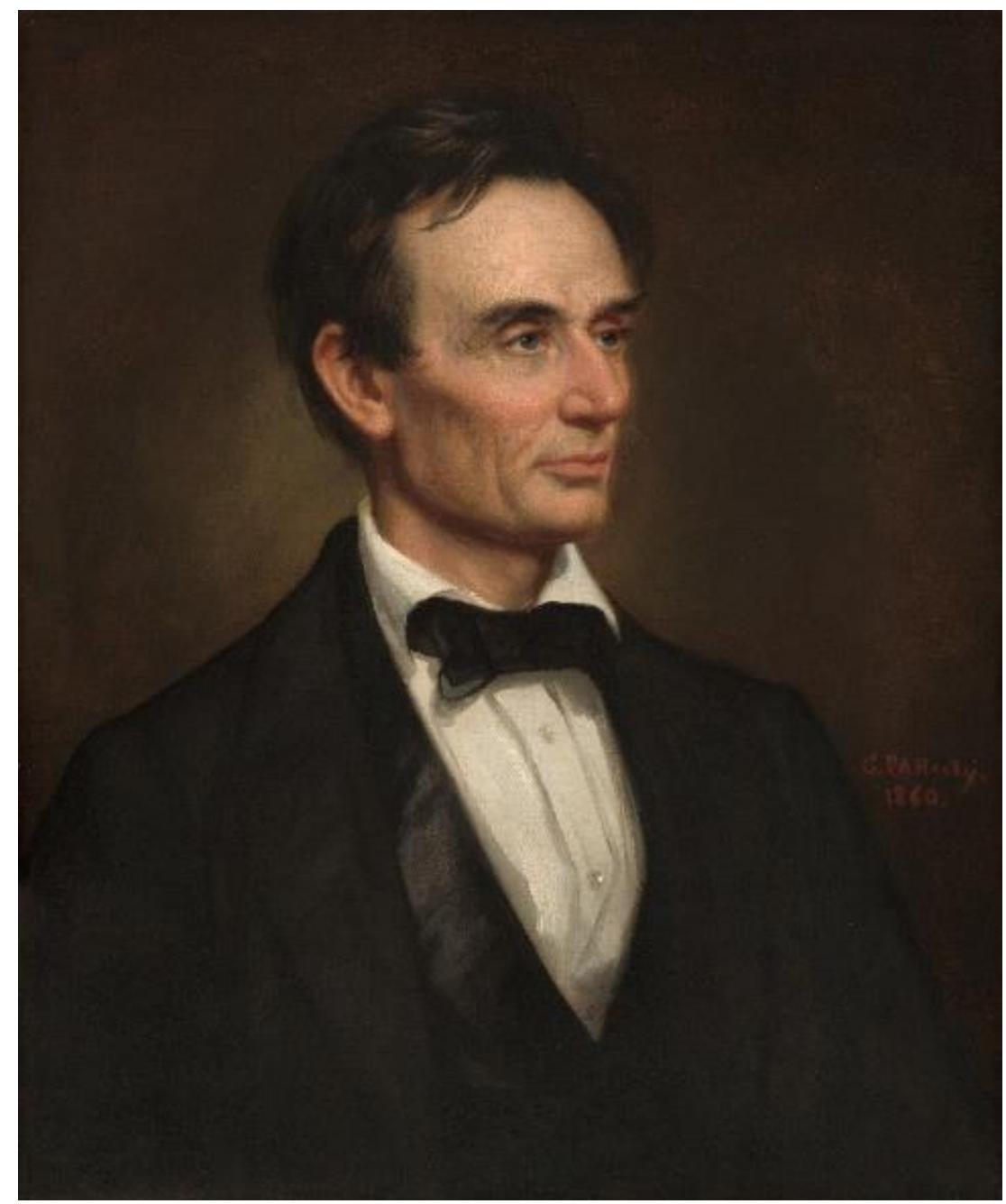

Görsel 11: George Peter Alexander Healy Abraham Lincoln, Amerika Birleşik Devletleri'nin 16. Başkanı, $1860^{11}$

${ }^{11}$ https://www.nga.gov/collection/art-object-page.166453.html

Uludağ Üniversitesi Fen-Edebiyat Fakültesi Sosyal Bilimler Dergisi Uludağ University Faculty of Arts and Sciences Journal of Social Sciences Cilt: 22 Sayl: 41 / Volume: 22 Issue: 41 


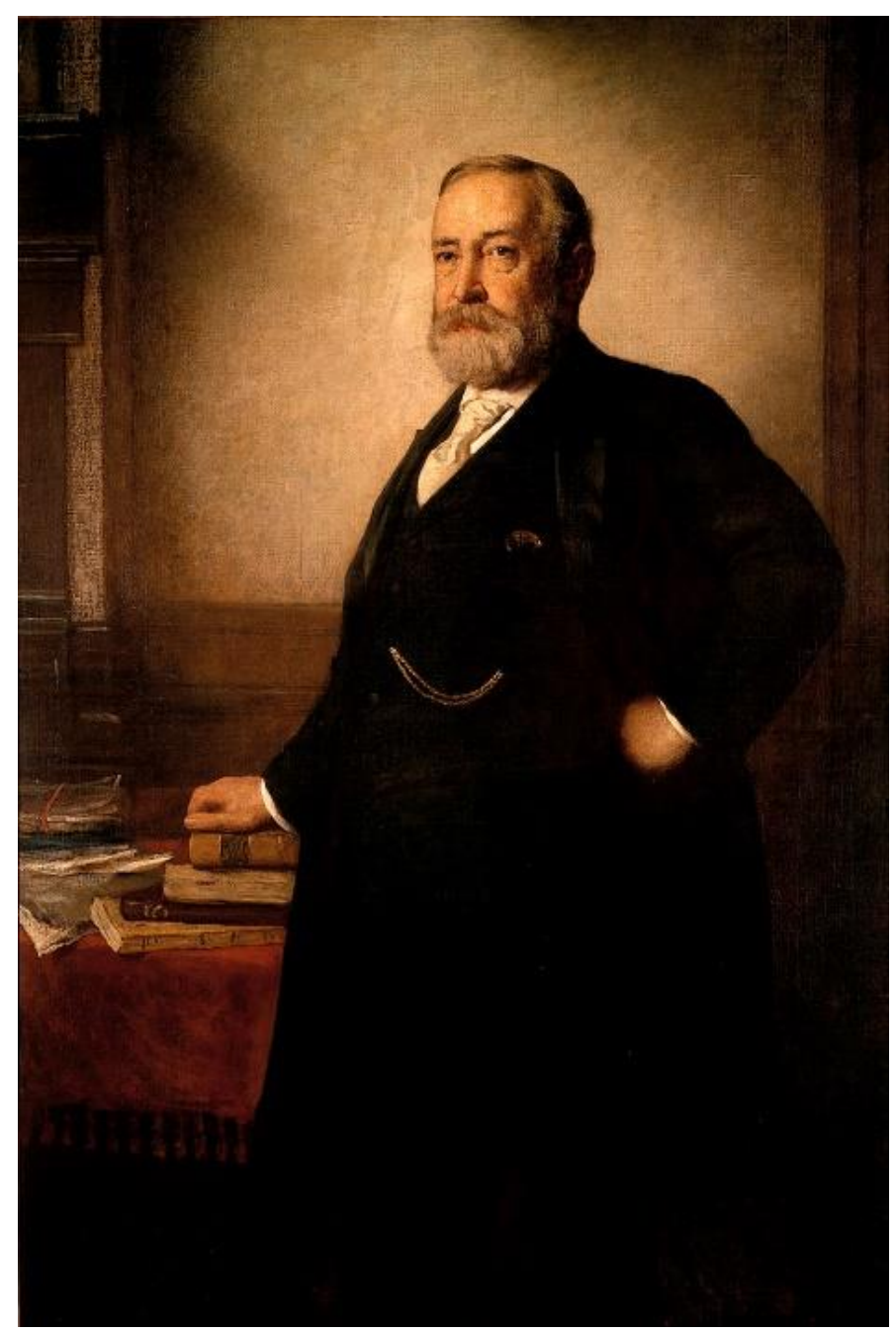

Görsel 12: Jonathan Eastman Johnson, Benjamin Harrison, Amerika Birleşik Devletleri'nin 23. Başkanı, $1895^{12}$

${ }^{12}$ https://www.whitehousehistory.org/galleries/presidential-portraits

Uludağ Üniversitesi Fen-Edebiyat Fakültesi Sosyal Bilimler Dergisi Uludağ University Faculty of Arts and Sciences Journal of Social Sciences Cilt: 22 Sayl: 41 / Volume: 22 Issue: 41 


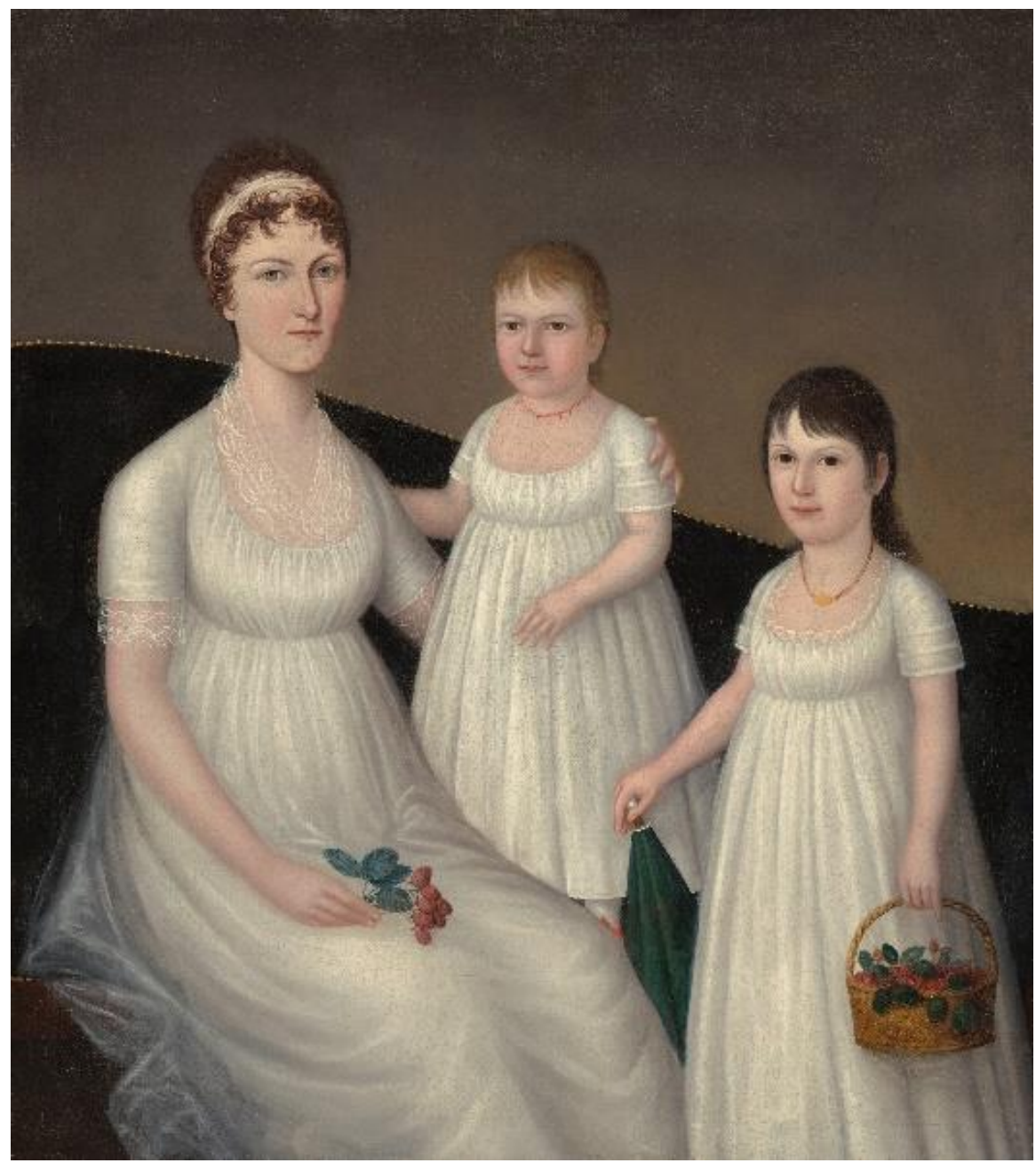

Görsel 13: Joshua Johnson, Grace Allison McCurdy ve Kızları, Mary Jane and Letitia Grace, $1806^{13}$

${ }^{13}$ https://www.nga.gov/collection/art-object-page.166457.html

Uludağ Üniversitesi Fen-Edebiyat Fakültesi Sosyal Bilimler Dergisi Uludağ University Faculty of Arts and Sciences Journal of Social Sciences Cilt: 22 Sayl: 41 / Volume: 22 Issue: 41 


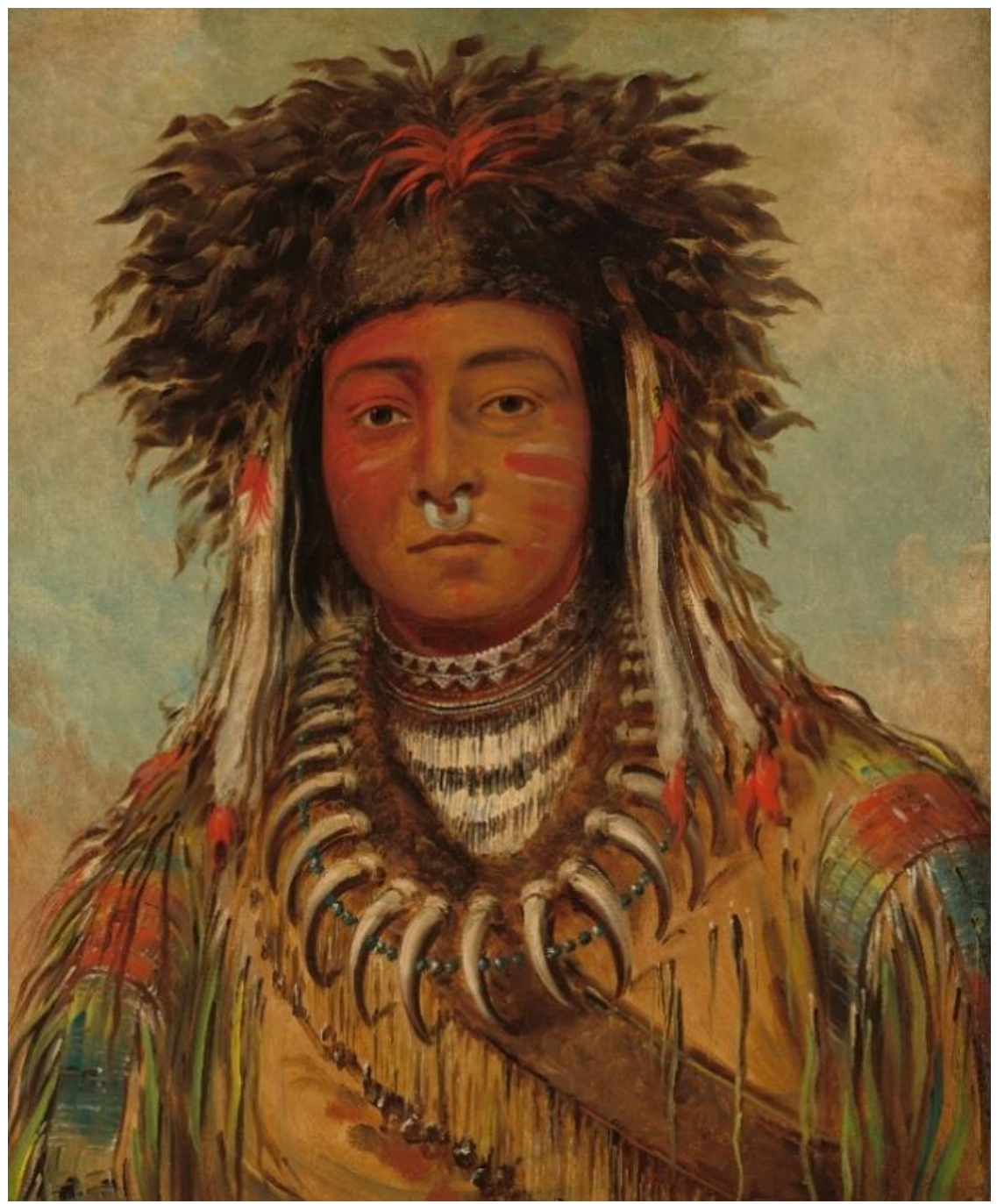

Görsel 14: George Catlin, Erkek Şef - Ojibbeway, $1843^{14}$

${ }^{14}$ https://www.nga.gov/collection/art-object-page.50657.html

Uludağ Üniversitesi Fen-Edebiyat Fakültesi Sosyal Bilimler Dergisi Uludağ University Faculty of Arts and Sciences Journal of Social Sciences Cilt: 22 Sayl: 41/Volume: 22 Issue: 41 


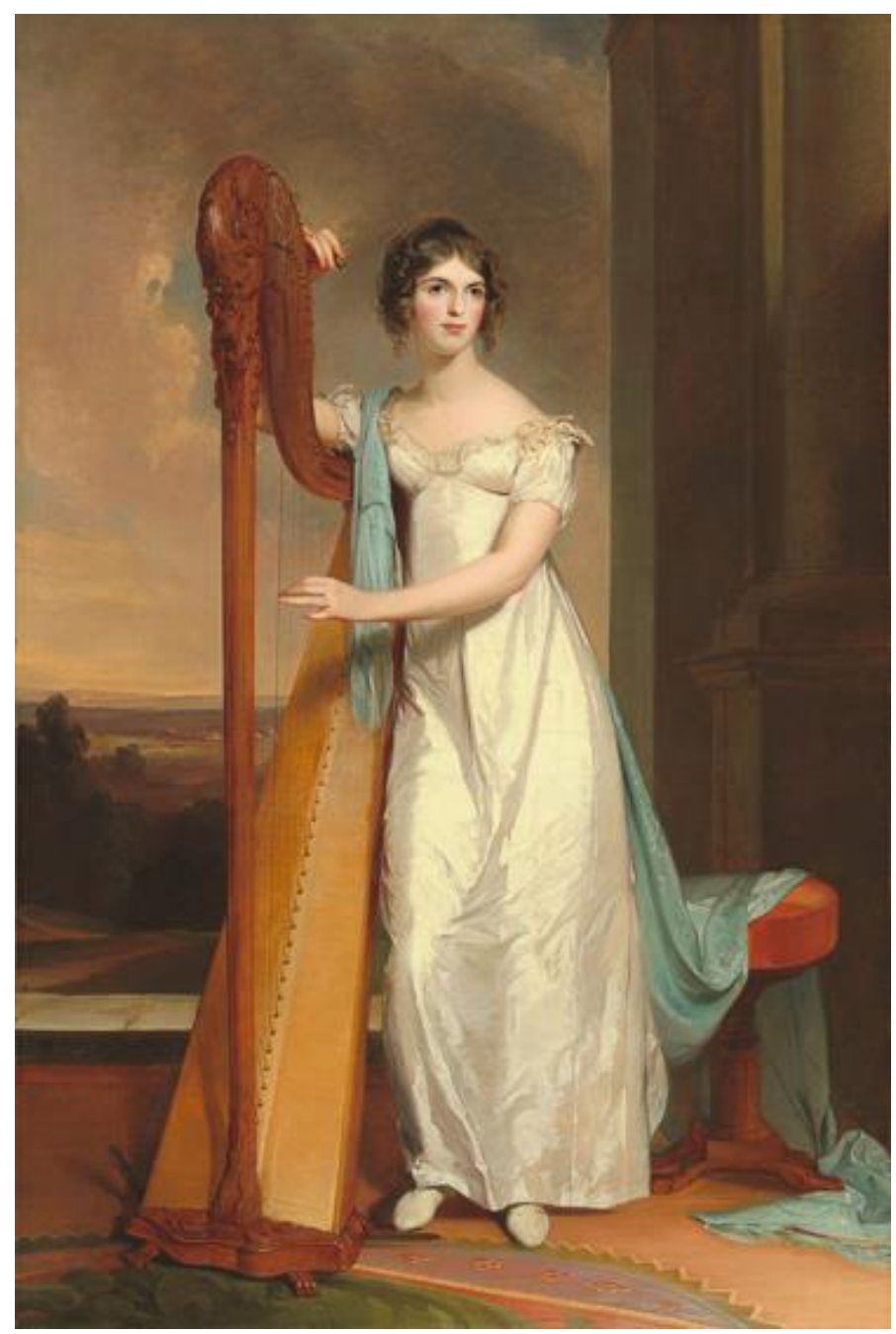

Görsel 15: Thomas Sully, Arplı Bayan: Eliza Ridgely, $1818^{15}$

\footnotetext{
${ }^{15}$ https://www.nga.gov/education/teachers/lessons-activities/uncoveringamerica/faces-portraits.html
}

Uludağ Üniversitesi Fen-Edebiyat Fakültesi Sosyal Bilimler Dergisi Uludağ University Faculty of Arts and Sciences Journal of Social Sciences Cilt: 22 Sayl: 41 / Volume: 22 Issue: 41 


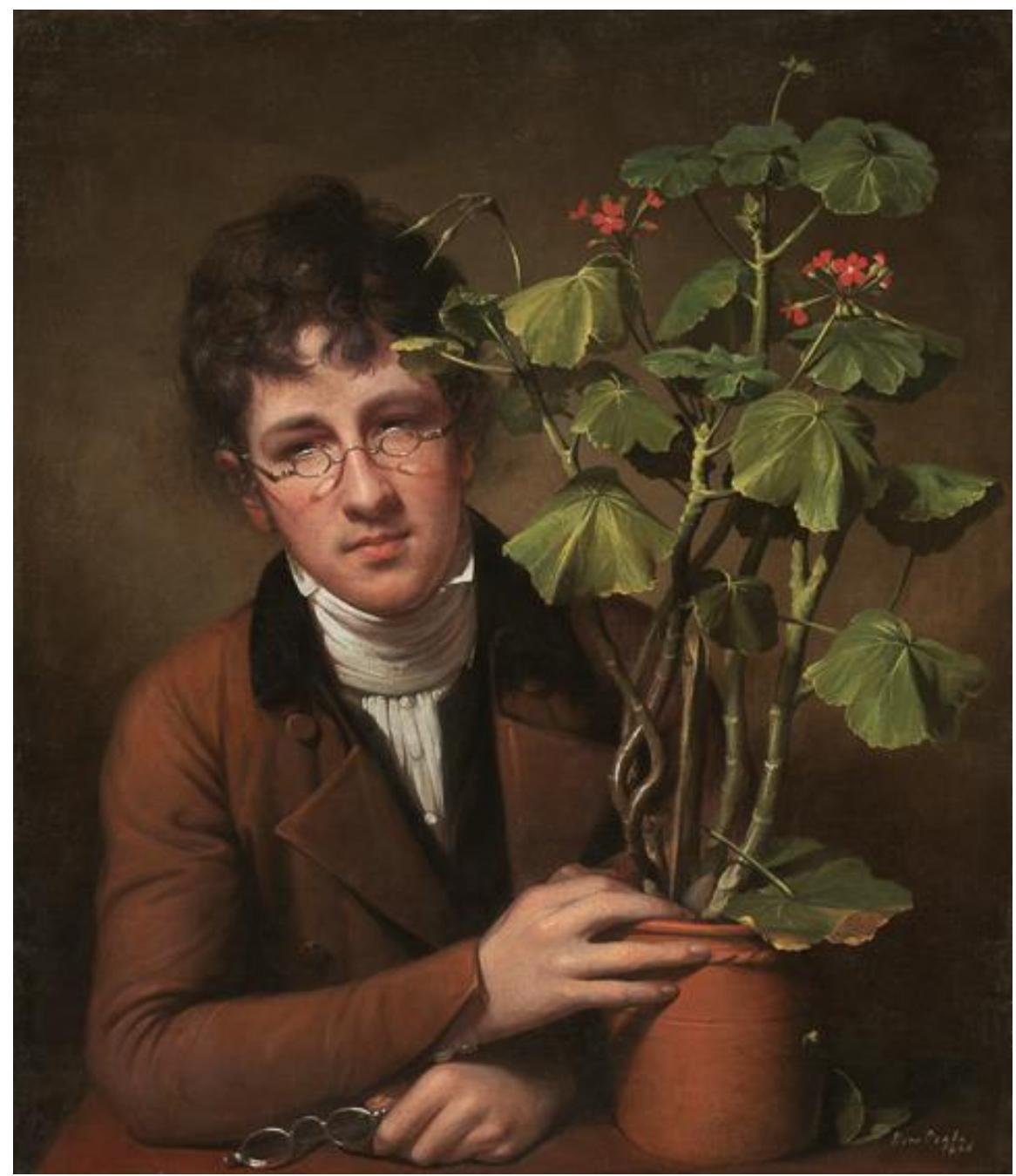

Görsel 16: Rembrandt Peale, Sardunya ile Rubens Peale, $1801^{16}$

\section{${ }^{16}$ https://www.nga.gov/education/teachers/lessons-activities/uncovering- america/faces-portraits.html}

Uludağ Üniversitesi Fen-Edebiyat Fakültesi Sosyal Bilimler Dergisi Uludağ University Faculty of Arts and Sciences Journal of Social Sciences Cilt: 22 Sayl: 41 / Volume: 22 Issue: 41 


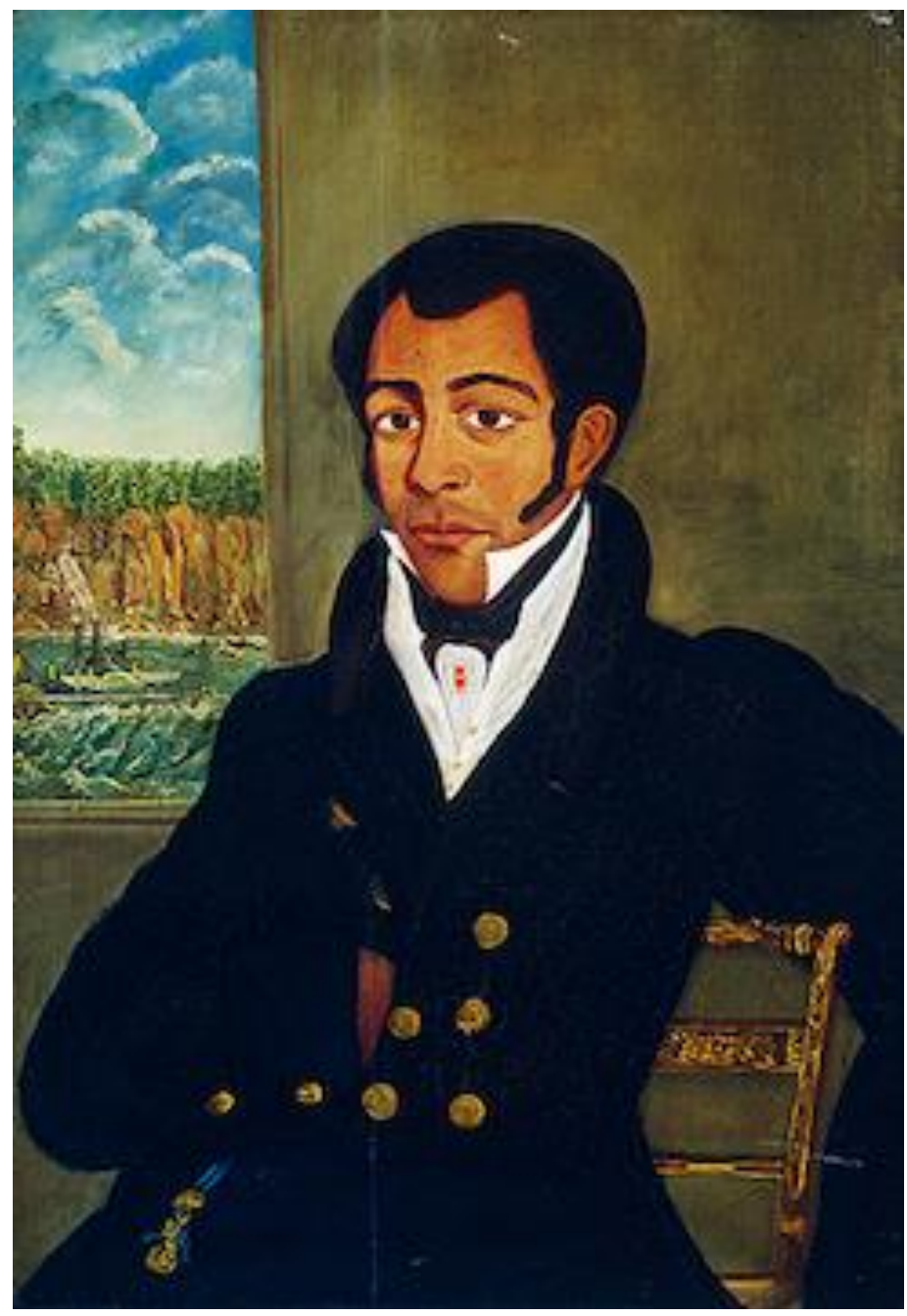

Görsel 17: Bir Gemi Görevlisi Portresi, $1829^{17}$

\section{${ }^{17}$ https://www.nga.gov/education/teachers/lessons-activities/uncovering- america/faces-portraits.html}

Uludağ Üniversitesi Fen-Edebiyat Fakültesi Sosyal Bilimler Dergisi Uludağ University Faculty of Arts and Sciences Journal of Social Sciences Cilt: 22 Sayl: 41 / Volume: 22 Issue: 41 


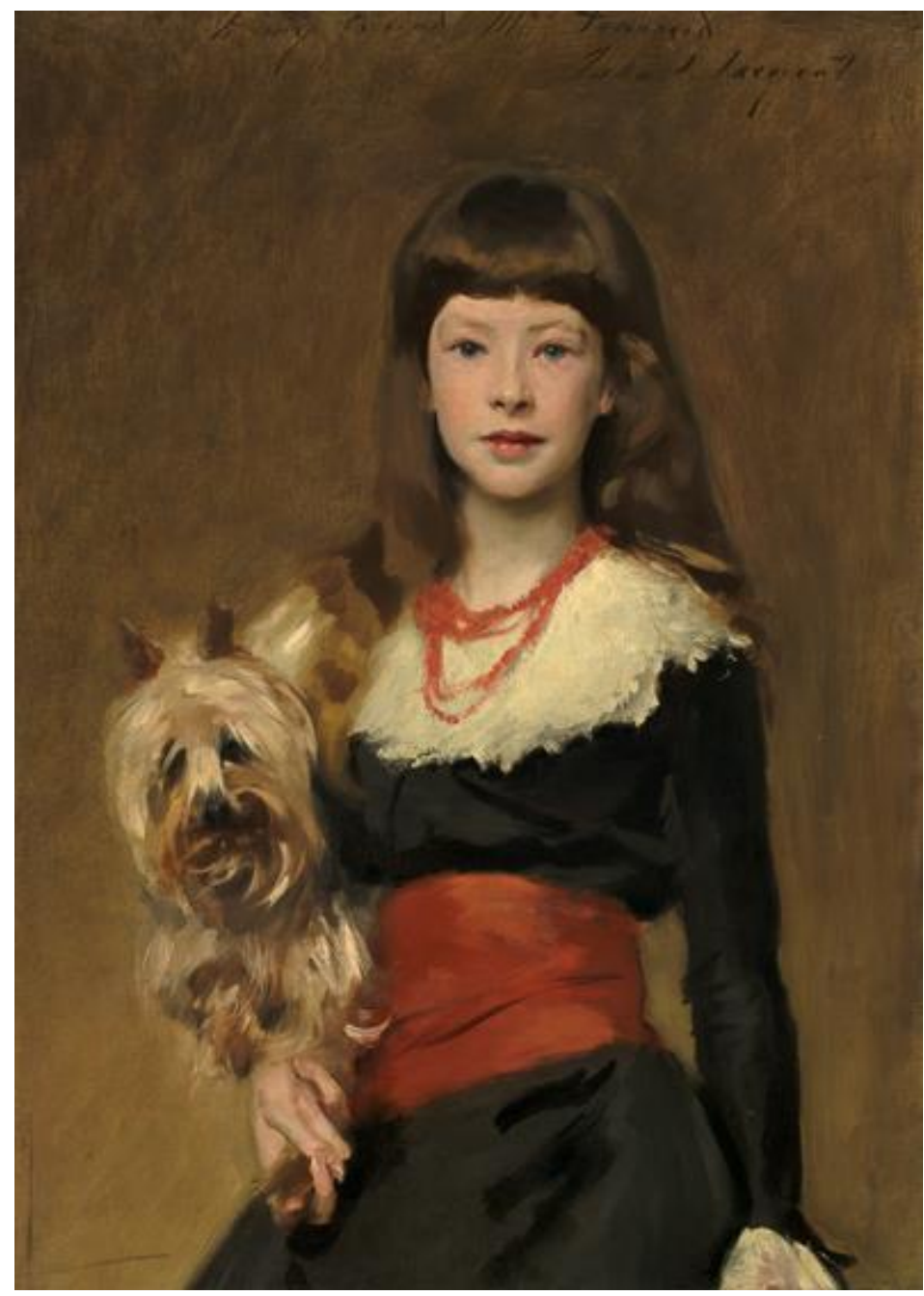

Görsel 18: John Singer Sargent, Bayan Beatrice Townsend, $1882^{18}$

\footnotetext{
${ }^{18}$ https://www.nga.gov/education/teachers/lessons-activities/uncoveringamerica/faces-portraits.html
}

Uludağ Üniversitesi Fen-Edebiyat Fakültesi Sosyal Bilimler Dergisi Uludağ University Faculty of Arts and Sciences Journal of Social Sciences Cilt: 22 Sayl: 41 / Volume: 22 Issue: 41 


\section{Sonuç}

17. ve 18. yüzyılın başlarında, tarihin en büyük göçlerinden biri olan bir göç dalgası Avrupa'dan Amerika'ya sıçramıştır. Bu şekilde Yeni Kita'ya kendi adetlerini gelenek ve göreneklerini resim sanatındaki alışkanlıklarını yeni gelen göçmenler taşımıştır.

20. yüzyıl öncesinde, konu olarak, Amerikalı ressamlar portre, manzara çalışmaları, Amerika'nın batısı ve hatıra sanatı çalışmaları üzerine yoğunlaşmışlardır. Ardından ressamların tarıma dayalı eski bir koloniden sanayileşmiş bir koloniye doğru yaşadığ 1 hızlı değişim ve dönüşümden kaynaklanan sosyal ve ekonomik değişiklikleri de çalışmalarında yansıtmışlardır. Yüzyıllar boyunca portreler, Amerikan halkının önemli bir kayıt belgesi olmuştur. Amerika'nın ilk başkanı düşünüldüğünde hafizalarda portreci Gilbert Stuart'n George Washington isimli çalışması canlanmaktadır. Portrelerini yaptıran kişiler aslında, bilinçli bir şekilde, sanatçılarla birlikte, gelecek nesiller tarafindan nasıl hatırlanmak istediklerine dair kalıcı bir belge sunmak istemişlerdir. 19. yüzyılın başlarında portre alanında çalışan az sayıdaki Afrikalı Amerikalı sanatçıdan biri olan Joshua Johnson, Grace Allison McCurdy (Bayan Hugh McCurdy) ve kızları, Mary Jane ve Letitia Grace gibi 1806 yılında bu türde birçok aile portresi çalışması hazırlamıştır. Toplumdaki hızlı değişimin dinamikleri, George Catlin'in Amerikan Kizılderilileri portrelerinden ikisi olan The Female Eagle - Shawano, 1830 ve Boy Chief - Ojibbeway 1843'te görülmektedir. İlk Amerikan halk portreleri, Kolonileşme ve Devrimci portreciliğin kardeşi olarak görülmüştür. Kolonileşme ve Devrimci sanat, İngiliz kültürel özelliklerine sürekli sadık kalmıştır çünkü Koloni dönemi insanları, İngiltere'deki çağdaşlarının satın aldığı gibi portreler satın almak istemişlerdir. Portre, kişinin yüksek sosyal konumunun bir göstergesi olmuş ve bu alışkanlık Amerika'nın seçkin bir sanatı olarak kabul edilen portre sanatını Yeni Cumhuriyet'in başlangıcına kadar sürekli kendisini devam ettirmiştir. Portrelerde, bazen insanlar kendileri için kişisel anlamı 
olan nesneler ve aksesuarlar ile resmedilmiştir. Sanat tarihinde, farklı bitkiler, saflık veya sadakat gibi çeşitli soyut nitelikleri sembolize etmiş, bitkiler, her müşterinin entelektüel uğraşları ve ilgi alanlarıyla doğrudan ilişkili olmuştur. Resimler, müşterilere yakın sanatçılar tarafından yapılan gerçekçi portrelerden oluşmuştur. West, Copley, Peale (17411827) ve Morse'un çalışmalarında, Kolonileşme, Devrimci ve Erken Cumhuriyet portresi örnekleri arasındaki farklılıklar görülmüştür. Hemen hemen her sanatçı, kişisel duygularına rağmen, klasik İngiliz tarzlarının İngiliz kültürünün mirasını yansıttığı, Amerikan'dan çok bir İngiliz sanat geleneğini içeren dönemde çalışmıştır. 19. yüzyılda Amerikalı portre sanatçıları İngiltere ile kültürel bağlarını koparmaya başlamıştır. Sanatçılar, milliyetçilik ve Amerikan kimliği fikirlerinin ateşli bir şekilde tartışıldığı dönemde çalışmalar üretmiştir. Sonrasında ortaya net bir Amerikan ruhu, yaratıcı ve farklı özelliklerle portrelerde kendini göstermiştir. Bu durum tüm sınıflara portre satın alma çağrısı oluşturmuştur.

John Smibert, Kolonileşme Dönemi'nde Amerika'da bir varoluş yaratmaya çalışan ilk portre ressamı olarak tarihe geçmiştir. Aslında bir İskoç göçmeni olan Smibert İngiliz geleneğini sürdüren ressamlardan birisi olmuştur. Copley ise İngiliz geleneğini sürdüren bir başka Amerikalı ressamdır. Kraliyet Akademisi'ndeki ilk çalışması olarak, 1777'de yaptığı Copley Ailesi'ni ve bir yıl sonra "Watson and Shark" isimli çalışmasını sergileyerek büyük bir başarı kazanmıştır. Bu başarısı ona eleştirmenlerin övgüsünü kazandırmış ve akademiye tam üye olarak kabul edilmiştir. Copley'nin en büyük tutkusu, Benjamin West'inki gibi çağdaş ressamların ve önemli olayların büyük tarihi resimlerini yapmak olmuş ve bu arzusunu hep devam ettirmiştir. West, 1772 y1lında tarih ressamı olarak Kral III. George'a hizmet etmesi için görevlendirilmiştir. Çoğu zaman Amerikalı bir ressam olarak tanımlansa da West, esasen Amerikalı ressamlar üzerindeki etkisi çok güçlü olan bir İngiliz ressamdır. Joshua Johnson ise, Amerika Birleşik Devletleri'nde bilinen 
ilk Afrikalı Amerikalı bir portre ressamı olarak tarihe geçmiştir. Kendisiyle ilgili olarak kaynaklarda çok az kesin bilgiye ulaşılmıştır. Konuları zengin Baltimore aileleri, orta ve işçi sınıfı kişilere kadar çeşitlilik göstermiştir. Gilbert Stuart Erken Cumhuriyet Dönemi'nin en başarılı ve üretken Amerikan portrecilerinden birisi olarak kabul edilmiştir. Rhode Islandlı olan Stuart, çağdaşlarının portre resmiyle ilgili fikirlerini onaylamamış ve potansiyelini sonuna kadar kullanmıştır. Daha çok George Washington portreleriyle tanınmıştır. Peale'nin Büyük Adamlar Galerisi fikri, onu sadece baş ve omuz bölgeleri olan "müze" portreleri yapmaya yöneltmiş çalışmalarının ilkini 1782'de tamamlamıştır. Peale birçok entelektüel ve siyasi liderin arkadaşı olması sebebiyle Washington, Thomas Jefferson, David Rittenhouse, Marquis de Lafayette dâhil olmak üzere savaşın ve yeni cumhuriyetin sayısız kahramanının resimlerini yapmıştır. Kardeşi James, yeğeni Charles Peale Polk ve oğulları Raphaelle, Rembrandt ve Rubens Peale'i ressam olarak eğitmiş ardından 1795 'te Philadelphia'da tek halka açık sergi olan ilk Amerikan sanatçılar topluluğu Columbianum'un kurucusu olmuştur. Vanderlyn, Ecole des Beaux-Arts'a tarih ressamı ve portreci FrancoisAndre Vincent ile çalışmalarına devam etmiş ve Louvre müzesindeki eski ustaların eserlerini kopyalamıştır. 1826 yılında sanatçıların hakları adına eğitimli, etkili ve yorulmak bilmeyen bir savaşçı olan Morse, yeni prestijini neredeyse kaybolmakta olan Amerikan Sanat Akademisi'nden ayrılan ve İlerici Ulusal Tasarım Akademisi'ni kuran bir grup genç sanatçıya liderlik etmek için kullanmıştır. Rubens Peale kardeşi Rembrandt Peale tarafından, bir doğa bilimci olarak ilgi alanlarını yansıtan bir sardunyayla canlandırmıştır. Resimde görülen bitkinin Amerika'da yetişen ilk sardunya olduğu belirtilmiştir. Amerika'da o zamana kadar sardunyalar egzotik ve nadir görülmüştür. Figürün çalışkan bir kişiliğinin olması gözlük ile belirtilmiştir. Ayrıca, gözlük Rubens’in zayıf görüşüne gönderme de yapmıştır. 
Portre yaptırmak ve sahip olmak sadece zengin kişilere özel olmuş ve sadece en zengin aileler, iki metre uzunluğundaki Arplı Leydi gibi büyük bir portreye sahip olmuşlardır. Portre, resmin masraflarına ek olarak, geniş duvarları ve yüksek tavanları olan geniş bir eve sahip olmayı da gerektirmiştir. Catlin, Yerli kabilelerin özerkliğini ihlal eden ABD yasalarının yaşamı boyunca geçişi nedeniyle Yerli Amerikalıların yok edilmesinden korkmuştur. Bu durum kendisini, yaşam tarzları tehdit altında olan insanları belgelemek için orta batı ve ovalardaki elliden fazla kabileyi ziyaret etme görevine sürüklemiş ve Amerikan Yerlilerini resimleyen bir ressam olmuştur. Prior ise en çok portreleriyle tanınmış ancak bazı manzara çalışmaları da yapmıştır. 1830 'da kendi kendini yetiştiren ressam, ailesini geçindirmeye yardımcı olmak için bir portre stüdyosu açmıştır. İlk başta siparişleri az olmasına rağmen, genç Healy, ise kendisine mesleğini resim yapmak olarak tavsiyede bulunan Thomas Sully'den önemli destek almıştır. Yetenekli olduğu kadar üretken de olan Healey 1867 'de altı yüzden fazla portre üretmiştir. Uzun yıllar Amerika Birleşik Devletleri'nin en önde gelen tür ressamı olan Eastman Johnson, ise kendi kuşağının yurtdışında kapsamlı eğitim alan ilk Amerikalı sanatçıları arasında olmuştur. Eserleri geleneksel ve yerli konuları daha gelişmiş teknik ve anlatımla birleştirerek iki nesil için önemli bir bağlantı görevi yapmıştır. Sargent, Avrupa'da hayattan zevk alan ve uzun süreli ziyaretleri olan uluslararası bir göçmen Amerikalılar ağının parçası bir ressam olarak pek çok başarılı çalışmaya imza atmıştır.

18. yüzyıl portreleri incelendiğinde figürler çoğunlukla baş ve gövdeden oluşup izleyiciye sağa dönük olarak betimlenmişlerdir.18. yüzyıl portrelerinde daha öncesinin devam eden İngiliz geleneği etkisi figürlerin romantik görünümleri ile sürdürülmektedir. Zengin kişiler, elitler, krallar, kraliçeler, gibi pek çok önemli ve saygın kişiler portre müşterileri arasında yer almıştır. Figürler kimi zaman tek, kimi zaman diğer aile üyeleriyle birlikte çoğunlukla iç mekânlarda görülmektedir. Vücudun tamamının göründüğü portreler daha kısıtlıdır. Işık kullanımı 
ve figürlerin giysileri tipik bir İngiliz etkisi olarak devam ettirilmiştir. 19. yüzyılda ise figürler daha doğal görünümde olmuş ve iç ve diş mekânlarda tasvir edilmişlerdir. Bazen figürlerin yanında bir nesne çiçek, gözlük veya müzik aleti gibi figürlerin bir özelliğini vurgulamak için tamamlayıcı veya sembolik ögeler de bulunmaktadır. 19. yüzyıl portrelerinde figürler izleyiciye sağa dönük olarak gösterilmişlerdir. 19. yüzyıl daha çok siyahi ressam ve yerlilerin konu edinildiği çalışmalarla dikkat çekerek daha özgün ve daha net Amerikan tarzının oluşumuyla göze çarpmaktadır. 19. yüzyıl resimlerinde varlıklı ailelerden ya da devlet başkanlarından orta ve işçi sınıfına kadar her kesimden daha fazla insanların portreleriyle karşılaşılmaktadır. Figürler çoğunlukla bu dönemde ayakta durur şekilde yansıtılmıştır. Bu dönemde ayrıca gövdenin neredeyse tamamının görüldüğü çalışmalar daha fazla olarak yer almaktadır.

\section{Bilgi Notu}

Makale araştırma ve yayın etiğine uygun olarak hazırlanmıştır. Yapılan bu çalışma etik kurul izni gerektirmemektedir.

\section{Kaynakça}

Barratt, C. R. (2003). Faces of a new nation: American portraits of the 18th and early 19th centuries. Metropolitan Museum of Art Bulletin, 61(1), The Metropolitan Museum of Art.

Barratt, C. R. \& Zabar, L. (2010). American portrait miniatures in The Metropolitan Museum of Art. The Metropolitan Museum of Art.

Baur, J. I. H. (1940). Eastman Johnson, 1824-1906: An American genre painter. Exh. Cat. The Brooklyn Museum.

Bearden, R. \& Henderson, H. (1993). A history of African-American artists from 1792 to the present. Pantheon. 
Bryan, J. \& Torchia, R. (1996). The mysterious portraitist Joshua Johnson. Archives of American Art Journal, 36(2), 2-7.

Burke, D. B. (1986). In pursuit of beauty: Americans and the Aesthetic Movement. The Metropolitan Museum of Art.

Chotner, D. (1992). American naive paintings. The collections of the National Gallery of Art Systematic Catalogue. Cambridge University Press.

Clark, C. (1992). American drawings and watercolors (Robert Lehman Collection Volume: 8). The Metropolitan Museum of Art.

Clark, R. J. (1972). The shaping of art and architecture in nineteenthcentury America. The Metropolitan Museum of Art.

Cook, B. F. \& Gardner, A. T. (1964). Illusion in painting. The Metropolitan Museum of Art Bulletin, 22(5), The Metropolitan Museum of Art.

Gardner, A. T. (1944). Memorials of an American Romantic. The Metropolitan Museum of Art Bulletin, 3(2), The Metropolitan Museum of Art.

Gardner, A. T. \& Feld, S. P. (1965). American paintings: A catalogue of the collection of the Metropolitan Museum of Art. Vol. 1: Painters Born by 1815. The Metropolitan Museum of Art.

Garrett, W. D. (1970). The first score for American paintings and sculpture, 1870-1890. Metropolitan Museum Journal, 3, The Metropolitan Museum of Art.

Harris, N. (1966). The artist in American society: the formative years, 1790-1860. Braziller. 
Hartigan, L. R. (1985). Sharing traditions: five black artists in America. Exh. cat. National Museum of American Art, traveling exhibition. Washington.

Healy, G. P. A. (1894). Reminiscences of a portrait painter. Chicago.

Hills, P. (1977). The genre painting of Eastman Johnson: the sources and development of his style and themes. New York.

Johnston, P. (1979). William Matthew Prior, itinerant portrait painter. Early American Life, 20-23, 66.

Kelly, F., Cikovsky Jr., N., Chotner, D., Davis, J. (1996). American paintings of the nineteenth century, part I. the collections of the National Gallery of Art Systematic Catalogue. Washington, D.C.

Kloss, W.. (1988). Samuel F. B. Morse. Harry N Abrams Inc.

Larkin, O. W. (1954). Samuel F. B. Morse and American Democratic Art. Little Brown.

Lee, C. (1929). Early American portrait painters: the fourteen principal earliest native-born painters. Yale University Press.

Lewison, F. (1998). G. P. A. Healy, 1815[sic]-1894, a success at home and abroad. American Artist, 32(54-59), 69-73.

Little, N. F. (1948). Willim M. Prior, traveling artist, and his in-laws, the painting hamblens. Antiques 53, 44-48.

Miles, E. G. (1995). American paintings of the eighteenth century. The collections of the National Gallery of Art Systematic Catalogue. Washington, D.C.

Miller, L. B. (Ed.). (1983-1991). The selected papers of Charles Willson Peale and his family. 3 vols. to date. New Haven and London.

Mathews, M. M. (1969). Henry Ossawa Tanner, American artist. Chicago and London. 
Mondello, S. (Ed.). (1990). The private papers of John Vanderlyn (17751852), American portrait painter. Lewiston, New York.

Oedell, W. (1981). John Vanderlyn: French Neoclassicism and the search for an American art. (Yayımlanmamıs doktora tezi). University of Delaware.

Prown, J. D. (1966). John Singleton Copley. 2 Cilt. Cambridge, Massachusetts.

Perry, R. A. (1976). Selections of Nineteenth-Century Afro-American Art. The Metropolitan Museum of Art.

Philadelphia Museum of Art. (1928). Portraits by Early American Artists of the Seventeenth, Eighteenth and Nineteenth Centuries, Collected by Thomas B. Clarke. Exhibition Catalogue.

Richardson, E. P. (1983). Brooke Hindle, and Lillian B. Miller. Charles Willson Peale and his world. New York.

Romero, D. (Ed.). (1985). Directory of American portrait artists. American Portrait Society.

Salvo, D. M. de, Berger, M., Parrish Art Museum, Wexner Center for the Visual Arts, Tampa Museum of Art. (1995). Face Value: American Portrait. Parrish Art Museum.

Smibert, J. (1995). Colonial America's first portrait painter (A Barra Foundation Book). Yale University Press.

Staiti, P. J. (1989). Samuel F. B. Morse. New York. 


\section{EXTENDED ABSTRACT}

The subject of this article is the American portraits before 20th century, consisting of the works of various North American painters, which later inspired many portrait painters. The problem with the subject is that, unfortunately, American portrait art is not well known in our country and there are not enough scientific publications written about it. The purpose of the study is to contribute to the literature by introducing the subject. In the study, the development of the American portrait art in the colonial and early republic periods, during the industrial revolution and up to the 20th century is presented in general terms. In the study, portrait art is also defined and examples of portrait art in Europe are mentioned. In the result section, selected examples of American portrait art were examined, and the general characteristics, similar and different points of portraits were tried to be revealed. With this study, it was also aimed to introduce the subject in Turkish and new researches who are interested, curious or want to do research. Besides, formalism and iconography methods were used in the research as a method. In the conclusion part, information about the clothes of children, women and men of the period was also obtained; a scientific resource in Turkish was prepared and introduced about American portrait art.

When it is thought on visual art in the United States or American art that means art produced in the United States or by U.S. artists. Besides, in the late 18th and early 19th centuries, artists mostly painted portraits, and some landscapes rooted mostly about English paintings. In the 19th century American cultural, political, and commercial daily life concepts transformed widely and various improvements and change, opportunities for the creation, exhibition, and sale of works of art increased swiftly. Artists benefitted from these opportunities producing greater numbers of works, turning the 19th century as one of the most significant periods at the history of American art. In the 18th and 19th century American portraiture art showed great change in style and subject. During the colonial period, portraiture art followed British template while Americans accepted themselves both politically and culturally British. When time passed, the shifting identities of clients, both politically and culturally, made artists to integrate to these new concepts on artistic style. In the first two decades at the 19th century, a unique and quintessentially American style appeared. Moreover, the new development at distinctive American identity and the becoming a middle class in $19^{\text {th }}$ century society explains why artists broke from British traditions. Americans wanted to participate in a material culture limited for selecting a few those paying highly costs requested by artists.

Historian Charles Sellers points out that this material culture was popular among growing new class of clerks, salesmen, and bookkeepers inspiring to bourgeois 
enterprises. Furthermore, this culture impacted farmers setting up the market, to become master mechanics who to be capitalist bosses, and manual workers mustering struggle against to middle class can be accepted as professional class while considering their roles about the Folk period. Artists run away from elite clientele. Lastly, Alice Winchester points out that the painters and the people were the same persons buying their pictures. To sum up, this new middle class was a group of Americans first ignored material culture benefitted their American identity and increasing capitalism to insert their own cultural roles. Moreover, this situation led to material culture appealing to increasing related to middle class. This search namely the analysis of culture is the examination of common shared notions of evaluating and answering cultural history of the United States of America. Portraits supply new meanings for the lives of those who have or feel such emotions. 